\title{
Insights on the systematics and morphology of Humiriaceae (Malpighiales): androecial and extrafloral nectary variation, two new combinations, and a new Sacoglottis from Guyana
}

\author{
Kenneth J. Wurdack', Charles E. Zartman ${ }^{2}$ \\ I Department of Botany, MRC-166, National Museum of Natural History, Smithsonian Institution, P.O. Box \\ 37012, Washington, DC 20013-7012, USA 2 Department of Biodiversity, National Institute for Amazonian \\ Research (INPA), Av. André, Araújo 2936, Aleixo, Manaus, Amazonas 69060-001, Brazil \\ Corresponding author: Kenneth J. Wurdack (wurdackk@si.edu)
}

Academic editor: A. Sennikov | Received 20 March 2019 | Accepted 28 April 2019 | Published 21 June 2019

Citation: Wurdack KJ, Zartman CE (2019) Insights on the systematics and morphology of Humiriaceae (Malpighiales): androecial and extrafloral nectary variation, two new combinations, and a new Sacoglottis from Guyana. PhytoKeys 124: 87-121. https://doi.org/10.3897/phytokeys.124.34679

\begin{abstract}
Humiriaceae have had little recent comparative morphological study except for their distinctive fruits. We surveyed the diversity of stamen structures in the family with consideration of dehiscence patterns and the evolutionary transitions between tetra- and disporangiate anthers. Novel interpretations of floral morphology support new combinations (Duckesia liesneri K.Wurdack \& C.E.Zartman, comb. nov. and Vantanea spiritu-sancti K.Wurdack \& C.E.Zartman, comb. nov.) for two species formerly in Humiriastrum. We investigated all eleven species of Sacoglottis for diagnostic features that may contribute to better species delimitations, and describe Sacoglottis perryi K.Wurdack \& C.E.Zartman, sp. nov. as an endemic of the Pakaraima Mountains in western Guyana. Finally, our survey across Humiriaceae for extrafloral nectaries (EFNs) revealed their presence on leaves of all extant species as adaxial basilaminar and/or abaxial embedded glands, in addition to the frequent occurrence of marginal glandular setae. The significance of inter-generic variation in gland position and anther morphology within the family are discussed.
\end{abstract}

\section{Keywords}

anthers, Duckesia, extrafloral nectaries, floral morphology, glands, Humiriastrum, Vantanea

Copyright K.J.Wurdack, C.E. Zartman. This is an open access article distributed under the terms of the Creative Commons Attribution License (CC BY 4.0), which permits unrestricted use, distribution, and reproduction in any medium, provided the original author and source are credited. 


\section{Introduction}

Humiriaceae contains approximately 65 species of extant trees and shrubs characterized by small white to greenish-cream (rarely red to pink) flowers and with a center of taxonomic richness in the Rio Negro Basin, the largest tributary of the Amazon River. The family is notable for its rich fossil record of distinctive, woody endocarps, and for its unusual biogeography as a nearly wholly neotropical family except for one species in tropical West Africa. The most comprehensive synoptic revision of the family or any of its eight constituent genera was published in 1961 by noted authority José Cuatrecasas. In that visionary work, Cuatrecasas radically restructured Humiriaceae with 24 new taxa, 33 new combinations, and the segregation of four new genera of which three (Duckesia [Ducke] Cuatr., Hylocarpa [Ducke] Cuatr., and Endopleura [Huber] Cuatr.) were monotypic Amazonian endemics. The genera as defined by Cuatrecasas (1961) are well delimited by clear discontinuities in floral bauplan, anther structure, endocarp structure, and/or placentation. In the subsequent half century advances in Humiriaceae systematics and morphology have been modest, including descriptions of 15 new species in four genera, floral anatomy (Narayana and Rao 1969-1977), palynology (Bove and Melhem 2000), and reconsideration of endocarp variation (Herrera et al. 2010, 2014). Due to the highly plastic leaf morphologies and complex infraspecific taxonomy (Cuatrecasas 1961, Cuatrecasas and Huber 1999), most species are poorly understood and research remains hampered by incomplete specimens that lack critical characters from both flowers and fruits.

Although Humiriaceae is clearly monophyletic and placed in Malpighiales, its relationships within the order (Wurdack and Davis 2009, Xi et al. 2012) and among constituent genera (Herrera et al. 2010, Bardon 2015) remain equivocal. The most robust, albeit still weak, ordinal placement to date by Xi et al. (2012) indicates Humiriaceae as sister to a parietal placentation clade (i.e., six families including Passifloraceae, Salicaceae, and Violaceae); however, this affiliation is not yet corroborated by compelling morphological evidence (see Endress et al. 2013). Divergence dating indicates it is among the oldest families of Malpighiales with a mean stem-group age of $105.7 \mathrm{Ma}$ (110.0-101.6, 95\% HPD) but with a relatively young crown-group age of $20.7 \mathrm{Ma}$ (32.1-10.4, 95\% HPD). Recent reevaluation of the fossil record provides evidence for an older crown-group diversification with at least three genera (Duckesia, Sacoglottis Mart., Vantanea Aubl.) by the early Oligocene ( $-30-28$ Ma; Herrera et al. 2010, 2014).

Glandular tissues on leaves, sepals, floral disc, and/or anthers have been reported for Humiriaceae (Cuatrecasas 1961). However, foliar glands that may function as extrafloral nectaries (EFNs), in particular, have been rarely noted (i.e., Metcalfe and Chalk 1950, Belin-Depoux 1993). Cuatrecasas (1961: 88) observed that Humiria J. St.-Hil. leaves are "dotted with glands near the margin on the lower side" but he provided few comments for the other taxa. This lack of basic knowledge is illustrated, for example, in the online World Checklist of Extrafloral Nectaries that only lists two genera (Sacoglottis, Vantanea) and three species with EFNs for the family (Weber et al. 2015). EFNs are abundant in other families of Malpighiales, especially Euphorbiaceae 
and Passifloraceae, although their distribution is likely also underreported across the order despite accounting for $26 \%$ of all EFN records in a recent tally (Weber and Keeler 2013). The adaptive value of EFNs for promoting mutualistic interactions with insects, especially ants, is well established (see Rico-Gray and Oliveira 2007). EFN ecology usually involves nectar secretion to attract ants that act as defenders to provide plant protection from herbivores.

Sacoglottis, the systematics focus of this study, is distinguished among the eight genera in having the lowest stamen number (10). Morphological and molecular evidence indicates a nested phylogenetic placement for Sacoglottis within the family (Herrera et al. 2010, Xi et al. 2012, Bardon 2015, Zartman et al., unpublished data), and consequently its androecium likely evolved via stamen reduction from higher numbers (mostly 20-30, but 100-200+ in some Vantanea). In its current circumscription (sensu Cuatrecasas 1961) the genus contains 10 species of trees distributed from Nicaragua to Brazil and Bolivia, as well as West African S. gabonensis (Baill.) Urb. A heretofore undescribed species of Sacoglottis with subglobose fruits has been known for many years among variously misidentified specimens from the northern Pakaraima Mountains of Guyana. While the earliest of the 20 known collections was made in 1951 by Bassett Maguire of The New York Botanical Garden, most are from later fieldwork sponsored by the Smithsonian Institution's Biodiversity of the Guiana Shield Program, including the 2012 Kamakusa Expedition (K. Wurdack, participant; Wurdack et al. 2013) which explicitly searched for and found the species.

We herein describe this new species of Sacoglottis and present comparisons of its vegetative and reproductive characters in relation to the often poorly known other species in the genus. We surveyed stamen structures from exemplars of all genera to provide more detailed information on features of systematics and evolutionary interest, especially relating to anther morphology and interpretation of sporangial reductions. As a result of this objective we also present new combinations based on novel interpretations of previously overlooked floral structure for two taxa. Finally, on noting the frequent occurrence of EFNs on Humiriaceae but little mention of them in the literature, we conducted a comprehensive EFN survey of all species to document their occurrence and any qualitative generic-level distinctions.

\section{Materials and methods}

Scanning electron microscopy (SEM) of untreated or rehydrated-ethanol transitioned then critical point dried (CPD) herbarium fragments was conducted with a Zeiss EVO MA15 (Carl Zeiss SMT, Inc., Peabody, Massachusetts) SEM at 5-10 kV after sputter coating with $10 \mathrm{~nm}$ of $\mathrm{C}+\mathrm{Au} / \mathrm{Pd}$ using a Leica EM ACE600 (Leica Microsystems GmbH, Wetzlar, Germany). Light microscopy (LM) was with an Olympus DSX100 (Olympus Corp., Tokyo, Japan) and extended focus imaging (EFI) for higher magnifications, or with a Zeiss Universal Compound Microscope. Androecial diversity of the family was broadly surveyed at US and then examined in detail with SEM and/or 
LM for representatives for each genus, including: Duckesia liesneri comb. nov., Henderson 933 (US); D. verrucosa (Ducke) Cuatrec., Ducke 2108 (US); Ducke [MG-16325] (US). Endopleura uchi (Huber) Cuatrec., Baker 58 (US), Assunção 605 (US). Humiria balsamifera var. imbaimadaiensis Cuatrec., Wurdack 4814 (US); H. crassifolia Mart., Cowan \& Soderstrom 2145 (US). Humiriastrum cuspidatum (Benth.) Cuatrec., Cid et al. 4264 (US), Ducke 243 (US); H. dentatum (Casar.) Cuatrec., Hatschbach 56145 (US); H. diguense (Cuatrec.) Cuatrec., Quizhpe et al. 612 (US); H. glaziovii (Urb.) Cuatrec., Landrum 4262 (US). Hylocarpa heterocarpa (Ducke) Cuatrec., Ducke [JBRJ30137] (US). Sacoglottis gabonensis, Gentry \& Pilz 32860 (US); S. guianensis Benth., Carvalho et al. 4346 (US); S. maguirei Cuatrec., Maguire et al. 30693 (NY, US); S. perryi sp. nov., Redden 7264 (US), Tripp 2984 (US). Schistostemon macrophyllus (Benth.) Cuatrec., Maas et al. 6577 (NY); S. oblongifolius (Benth.) Cuatrec., Maas et al. 6804 (US). Vantanea bahiensis Cuatrec., Belém \& Magalhães 748 (US); V. compacta (Schnizl.) Cuatrec., Hatschbach 21265 (NY); V. depleta McPherson, Hammel \& Trainer 12954 (MO), McPherson \& Stockwell 10892 (US); V. micrantha Ducke, Ducke [JBRJ-30135] (US); V. peruviana J.F. Macbr., Rimachi 4577 (US); V. spiritu-sancti comb. nov., Silva et al. 1436 (US). Stamen vasculature was examined after clearing with aqueous 5\% $(\mathrm{w} / \mathrm{v})$ sodium hydroxide, followed by saturated chloral hydrate. For floral anatomy of Vantanea spiritu-sancti, buds were cleared of tannins with Stockwell's bleach, paraffinembedded, sectioned at $10 \mu \mathrm{m}$, and stained with toluidine blue O. Stamen structure descriptions follow the work of Endress (e.g., Endress and Stumpf 1990, 1991).

Character states in Tables 1, 2 were based, except where noted, on new primary observations. Fruits vary in size and shape among Sacoglottis species, but distinguishing true size differences from developmental differences in their slow maturing fruits is to some degree unclear given that most fruits are collected immature. Length-to-width ratios $(1 / \mathrm{w})$ were used as a simple shape proxy to reflect degree of elongation in their basic ellipsoid shape, and a key character in distinguishing fruiting collections of the newly described species. Based on the many available fruits of the new species at various developmental stages (although we lack truly ripe fruit), this ratio is apparently stable across a range of sub-maturity. Similar large sample sizes were not available for most other Sacoglottis species. A full understanding of inflorescence structure in Sacoglottis with its multiple orders of often dichotomous branching is beyond the scope of our study and would be difficult to carefully assess with incomplete herbarium collections. However, we did quantify peduncle and pedicel lengths; the latter usually vary several-fold within an inflorescence.

Representative leaves from nearly all Humiriaceae species and varieties were surveyed with LM for the presence of foliar glands and leaf margin features. Type collections were utilized where possible to avoid identification uncertainty, and multiple specimens were studied, especially for taxa with glands characterized as scarce or potentially absent. In some cases, distinguishing between plant structures and leaf damage, which creates circular depressions with marginal scarring, was difficult. We employed additional search criteria of expected location and positional patterns, although the laminar glands of some species are clearly sparse and erratically distributed. 


\section{Results}

\section{Androecial morphology}

The flowers of Duckesia verrucosa have (22-)25 stamens of two types, including five fertile antepetalous that each alternate with a group of 4-5 sterile on less stout filaments of varying lengths. One stamen per sterile group is usually as long or longer (clearly the medial antesepalous stamen when five per group) than the fertile stamens and the rest shorter. The filaments are subulate, complanate, basally very short-connate, proximally short-papillose, and distally smoother (especially so on the fertile stamens). Abnormally short filaments (1/3-1/2 of the normal length) lacking anthers rarely substitute for sterile stamens; these are likely the occasional staminodes reported by Cuatrecasas (1961). The filaments each contain a vascular bundle that continues into the connective protrusion for nearly its entire length, and is distally branched in the fertile but unbranched in the sterile anthers. Anthers are dorsifixed below midlength, glabrous, lack stomata, caducous, and have elongate connective protrusions, which are especially thickened and fleshy in the fertile anthers. The fertile anthers are tetrasporangiate, with a pair of larger sporangia (pollen sacs) positioned dorsally at the level of the filament insertion, and a pair at the base that are slightly smaller and nearly perpendicular to the dorsal pair (Fig. 1A, B). Dehiscence of the four thecae is by flap-like valves that open from the ventral side for each lateral sporangium and move dorsally (outward), or for a basal sporangium move from distal to proximal (drop downward; Fig. 1B). The sterile anthers consist of connectives with protrusions that are thinner than those of the fertile anthers and have little trace of sporangia (Fig. 1F); those connectives can be prolonged and misshapen due to packing in bud and form filling around the fertile anthers. The 20 stamens of Duckesia liesneri comb. nov. are of two types with five long antesepalous and 15 short. The filaments are subulate, complanate, connate for up to $1 / 3$ of their length, smooth, and contain a vascular bundle that continues into the connective protrusion and is usually unbranched (rarely with short stubby branches distally). The anthers are all fertile, tetrasporangiate and similar to $D$. verrucosa; however, the pairs of sporangia lack size differentiation and are close together rather than well-separated (Fig. 1C). In bud, both species have stamens with straight filaments that are longer than the anthers.

The flowers of Endopleura have 20-22 stamens (to 30, fide Cuatrecasas 1961) of two types. Five antepetalous and five antesepalous long stamens are tetrasporangiate with separated lateral (dorsal) and basal pairs of sporangia (Fig. 1E, I). The 10+ short anthers alternating with the long type are usually disporangiate by missing the lateral pair, or rarely with no (sterile) or three sporangia (Fig. 1D). Filaments are subulate, complanate, basally very short-connate, and short-papillose nearly their entire length; each contains a vascular bundle that continues into the connective protrusion where it is unbranched or distally branched (branching does not appear correlated with stamen type). In bud the filaments are straight with slightly sinuous tips for the longer type (likely due to packing), and as long or longer than the anthers. Anthers are dorsifixed below midlength, glabrous, versatile, lack stomata, caducous, and variously shaped due 


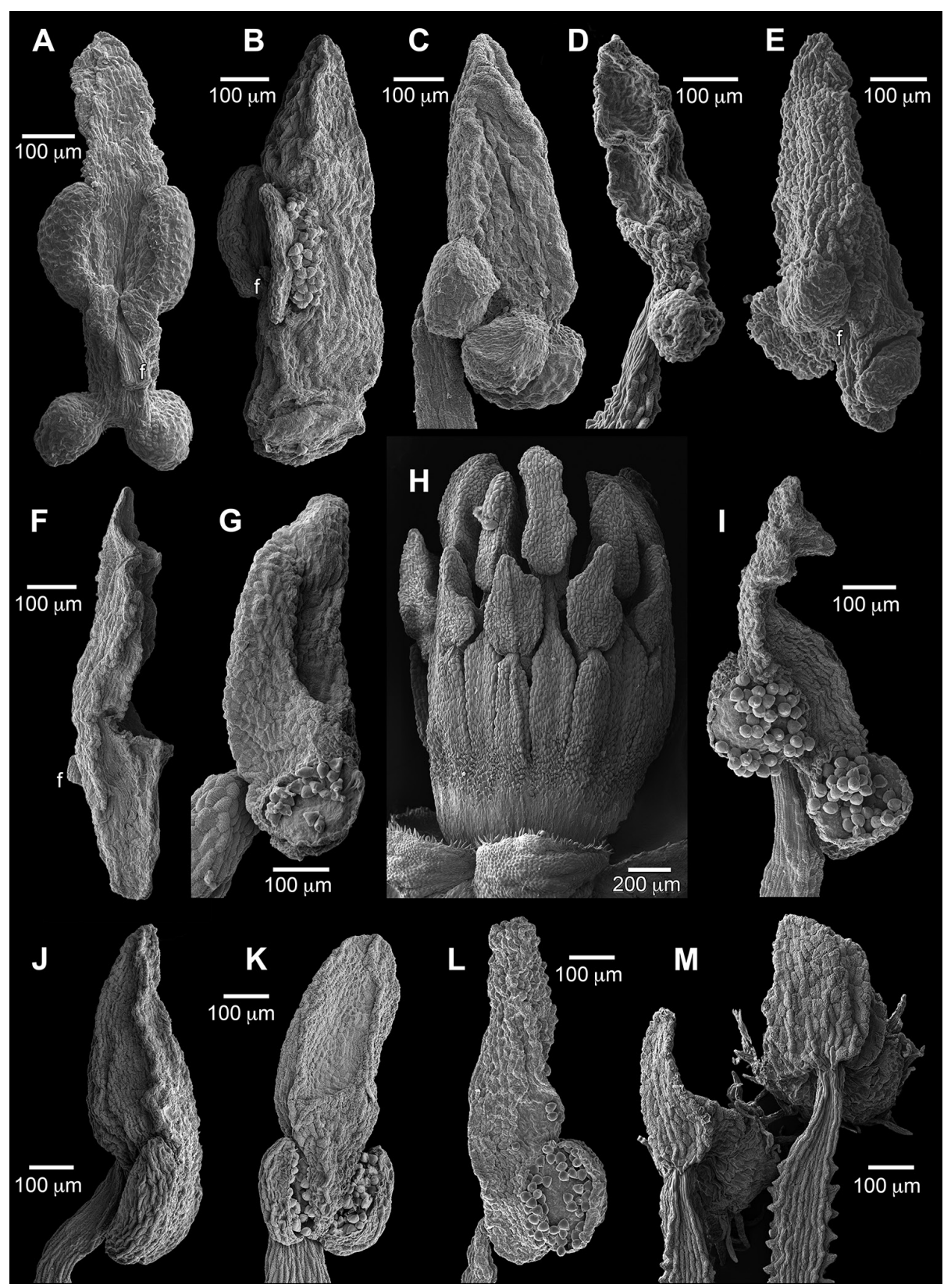

Figure I. Stamen structure of Humiriaceae. A Duckesia verrucosa tetrasporangiate anther, dorsal B Duckesia verrucosa tetrasporangiate anther, lateral C Duckesia liesneri tetrasporangiate anther, lateral D Endopleura uchi disporangiate anther, lateral E Endopleura uchi tetrasporangiate anther, lateral F Duckesia verrucosa sterile anther, lateral $\mathbf{G}$ Humiriastrum cuspidatum disporangiate anther, lateral $\mathbf{H}$ Humiriastrum cuspidatum androecium, dorsal I Endopleura uchi tetrasporangiate anther, lateral J Humiriastrum dentatum disporangiate anther, lateral $\mathbf{K}$ Humiriastrum dentatum disporangiate anther, ventral $\mathbf{L}$ Humiriastrum diguense disporangiate anther, lateral $\mathbf{M}$ Humiria balsamifera var. imbaimadaiensis stamen cluster with 2 of 3 types, dorsal. $\mathrm{f}$ = filament attachment location. Sources: A, B, F Ducke $2108 \mathbf{C}$ Henderson 933 D, E, I Assunção 605 G, H Cid et al. 4264 J, K Hatschbach 56145 L Quizhpe et al. 612 M Wurdack 4814 (all US.) 
to distortions of the usually thickened, elongate connective protrusions from packing in bud (e.g., Fig. 1D with impressions of adjacent sporangia indenting the connective protrusion). The four thecae and dehiscence lines resemble those of Duckesia.

The flowers of Humiria have 20 stamens of three types, including five long antesepalous, 10 short and adjacent to antesepalous, and five antepetalous of intermediate length. Two (Cuatrecasas 1961) or three (Narayana and Rao 1973b) anther types have been previously reported, and we observed three types across multiple species and varieties examined. The filaments are subulate, complanate, and connate up to half their length to form a smooth androecial tube. The free tips are smooth dorsally but otherwise papillose along their margins where the projections interdigitate, and more sparingly short-papillose ventrally. The filaments of $H$. balsamifera var. imbaimadaiensis each contain a vascular bundle that continues into connective protrusion for nearly its entire length and is unbranched. Anthers are disporangiate, dorsifixed at or near their base, versatile, lack stomata, and caducous (Fig. 1M). The thickened, elongate apical protrusions are glabrous and variously shaped according to their type and packing in bud; the protrusions of the long stamens wrap over and conform to the stigmas. The two sporangia are coarsely hirsute, slightly divergent, and each dehiscent from the ventral side via a dorsal hinge (opening outward).

The flowers of Humiriastrum (Urb.) Cuatrec. have 20 stamens of two types, including 10 long antesepalous and antepetalous, and 10 short that are adjacent to the long (Fig. $1 \mathrm{H})$. The filaments are subulate, complanate, basally short- to half-connate, and smooth to sparsely short-papillose; each contains a vascular bundle that continues into the connective protrusion for half to nearly all its length, and is unbranched $(H$. diguense) or branched ( $H$. dentatum). In bud, the filaments are straight and longer than the anthers. Anthers are disporangiate, dorsifixed below midlength, delicately attached, glabrous, lack stomata, caducous, and have large, thickened apical protrusions, which for the long stamens can wrap over the stigmas with tips folded inward. Cuatrecasas (1961: 49) described the "thecae of anthers basal" in Humiriastrum versus "inferolateral" in Sacoglottis and Schistostemon. However, this distinction is blurred as both orientations occur in Humiriastrum. In $H$. dentatum, the sole species studied by Narayana and Rao (1973a), the two sporangia are slightly divergent (V-shaped), and dehiscent from the ventral side in the manner of the other disporangiate genera (Fig. $1 \mathrm{~J}-\mathrm{K})$; this configuration also characterizes $H$. glaziovii. Most of the remaining species in the genus have variations on (sub)parallel (not divergent) basal sporangia. For example, the sporangia of $H$. cuspidatum (Fig. 1G) are small, positioned at the anther base so as to be perpendicular to the connective long axis, and each dehiscent by a valve opening distal to proximal (drops downward). In $H$. diguense, the sporangia of the long stamens are oriented parallel to the connective long axis, and each open from the dorsal side via a ventral hinge (Fig. 1L); the short stamens have smaller, often asymmetrically paired sporangia. This dehiscence configuration is opposite of that found in $H$. dentatum, although it also differs in other details such as sporangia not divergent.

The flowers of Hylocarpa (examined with LM from a single, young bud and additional fragments) have 20 stamens of two types, including 12 fertile and the rest sterile (30 stamens with 5-15 fertile according to Cuatrecasas 1961), whose exact ar- 
rangement was not determined. The filaments are straight, not obviously complanate, shorter than the anthers, and smooth; the papillose filament ornamentation reported by Cuatrecasas (1961) may occur later in development. Fertile anthers are disporangiate, dorsifixed, attached in their proximal third, glabrous, and have large, carnose, clavate connectives that are unlike the tapering apical protrusions in the other genera; sterile anthers are slightly larger with connectives that are more irregularly shaped (Fig. 3G). The basal sporangia are small and divergent on the V-shaped connective base.

The flowers of Sacoglottis have 10 stamens of two types, including five long antesepalous and five short antepetalous. The filaments are subulate, complanate, basally connate to form an androecial tube, and smooth; each contains a vascular bundle that continues into the connective protrusion for nearly its entire length and distally usually bears short stubby branches. In bud, the filaments are straight and longer than the anthers. The filament width and length of connation (1/10-2/3 of total length) vary between species and can be diagnostic (see Table 2). Anthers are disporangiate, dorsifixed near their midlength or just below, versatile via a delicate attachment, glabrous, lack stomata, and caducous (Fig. 2A, B). The two sporangia are slightly divergent (Vshaped) with dehiscence lines on the ventral side that extend over both upper and lower shoulders. The stomium of each sporangium is thus eccentric with the elliptic flap-like valve longer than its dorsal hinge which is much thinner than the thickened valve lip (Fig. 2B, C). The anther connective has a thick apical protrusion, which in bud for the short stamens is compressed against and takes on the shape of the bases of the long stamens, leading to a degree of dimorphism between the two anther-types from this space filling effect. Thin staminode-like processes were rarely observed between the stamens of Sacoglottis guianensis (Fig. 2D). The anthers of S. gabonensis are the largest in the genus (to $1.5 \mathrm{~mm}$ long for the long stamens; $2 \mathrm{~mm}$ fide Cuatrecasas 1961), but structurally otherwise resemble the other species. We reexamined the limited remaining floral material on the type of $S$. maguirei (anthers were not seen) and could confirm it has a Sacoglottis bauplan with 10 stamens of two alternating types; its filaments resemble those of the other species and are short, wide, and connate half their length. This species otherwise vegetatively more closely resembles small-leaved species of Humiriastrum.

The flowers of Schistostemon (Urb.) Cuatr. have 20 stamens of three types, including five long trifurcate antesepalous, 10 short and adjacent to the antesepalous, and five of medium length antepetalous, and have 30 anthers (Fig. 2E, F). The filaments resemble those of Sacoglottis and are subulate, complanate, basally connate to form an androecial tube, and smooth. However, the five long stamens have a trigonous (in transverse section) free portion of the filament that then distally trifurcates, with each branch bearing an anther such that each stamen has three anthers. The lateral (dorsal) branches in the plane of the staminal tube are shorter, and the central (ventral) branch is longer and bent slightly inward (Fig. 2G). The five trifurcate stamens of S. oblongifolius have three co-lateral vascular bundles per filament that diverge at the branched apex with one bundle serving each anther, while the remaining 15 stamens each have a single bundle; each vascular bundle continues into the connective protrusion to nearly the tip 


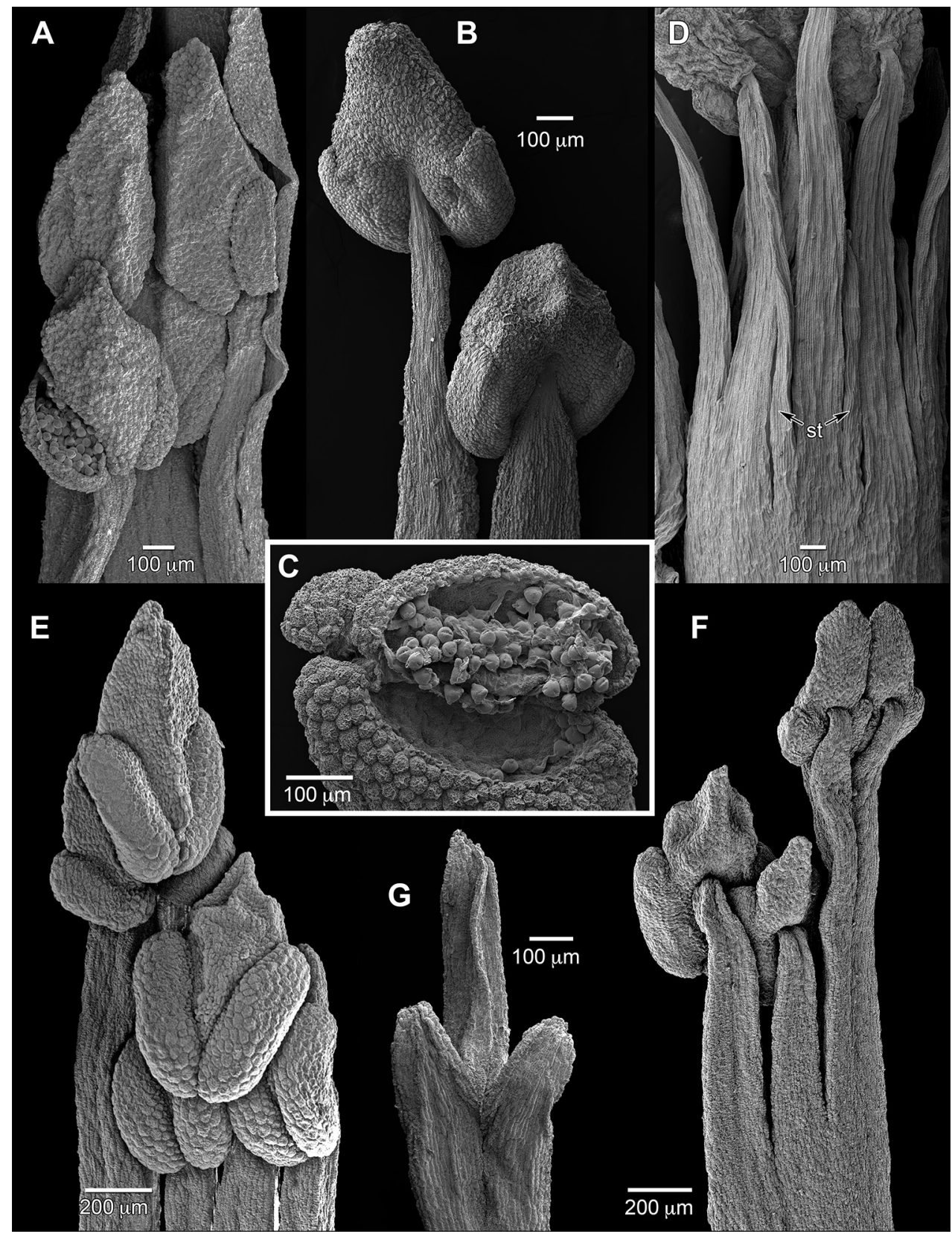

Figure 2. Stamen structure of Humiriaceae. A Sacoglottis perryi stamen cluster of 2 types, ventral B Sacoglottis perryi stamen cluster of 2 types, dorsal C Sacoglottis perryi short-stamen anther with open stomium and pollen D Sacoglottis guianensis androecium with interstaminal staminodes (st), dorsal E Schistostemon macrophyllus stamen cluster of 3 types, ventral F Schistostemon macrophyllus stamen cluster of 3 types, dorsal G Schistostemon oblongifolius trifurcate filament tip, dorsal. Sources: A-C Tripp 2984 D Carvalho et al. 4396 E, F Maas et al. 6577 G Maas et al. 6804 (all US). 
and distally usually bears short, stubby branches (Fig. 3E). The disporangiate anthers of Schistostemon are very similar in morphology to those of Sacoglottis, including in details of attachment, space-filling protrusion dimorphism, branched vasculature in the apical protrusion, slight sporangia divergence (V-shaped), and dehiscence by valves that open from the ventral side and move dorsally (outward). However, the lateral anthers of each trifurcate stamen are slightly reduced in size relative to the central one.

The flowers of Vantanea vary in stamen number across the species, ranging from 15-28 in $V$. depleta to $>200$ in $V$. maculicarpa Sabatier \& J. Engel (fide Engel and Sabatier 2018), and vary in length from $3 \mathrm{~mm}$ in $V$. spiritu-sancti to $35 \mathrm{~mm}$ in $V$. guianensis Aubl. Stamen number can also vary within collections and species, and the positions of different types (lengths) relative to sepals and petals is indeterminate with higher numbers. The filaments are much longer than the anthers, thin, subcomplanate, of multiple slightly different lengths within a flower, usually distally sinuous in bud which is retained at anthesis, and can be basally connate to form discrete whorls or less ordered. In $V$. peruviana, an inner cluster is differentiated by greater connation and papillose filaments, while the outer stamens are less connate and smooth. In $V$. micrantha, stamen whorls are poorly differentiated and all filaments are smooth. In species with relatively few, short stamens (i.e., $V$. depleta, $V$. spiritu-sancti), the filaments are clearly a single file and complanate; each contains a vascular bundle that continues into the connective protrusion for half its length and is unbranched. Anthers are tetrasporangiate with two thecae, each containing an internal septum that delineates two pollen sacs per theca. They are dorsifixed at midlength to lower third, versatile, glabrous, lack stomata, and caducous; dehiscence is by a single longitudinal slit per theca that opens widely (Fig. 3A-D). Thecae are variable in size, shape, symmetry, and orientation among the species, including elongate, extending most of the length of the anther and lateral (V. compacta), or shorter (to subovate), limited to the lower half of the anther, and slightly divergent $(\mathrm{V}$-shaped in $V$. depleta). A theca can be (mono)symmetric, or asymmetric due to size differences between the two constituent sporangia or lateral shifts of them relative to each other. The connective protrusions are thickened and elongate, with some variation according to species such that larger protrusions appear correlated with smaller sporangia (see Fig. 3A-D). In V. spiritusancti, the 20 stamens are clearly of three alternating lengths in the manner of Schistostemon including five long antesepalous, 10 short and adjacent to the antesepalous, and five of medium length antepetalous. Its subulate filaments are the shortest in the genus at $2-3 \mathrm{~mm}$, basally connate to $1 \mathrm{~mm}$, distally slightly sinuous, and minutely papillose. The anthers are similar in structure to other Vantanea spp., with four sporangia, internal septa, and dehiscence by longitudinal slits (Fig. 3D). In V. depleta we found a variable stamen number with 22-28 for Hammel \& Trainer 12954, and verified a lower range of 15-18 for the type collection, McPherson \& Stockwell 10892, as had been reported by McPherson (1988). Its stamen structure of alternating lengths with the longest approximately antesepalous resembles that of $V$. spiritu-sancti, although less fixed. 


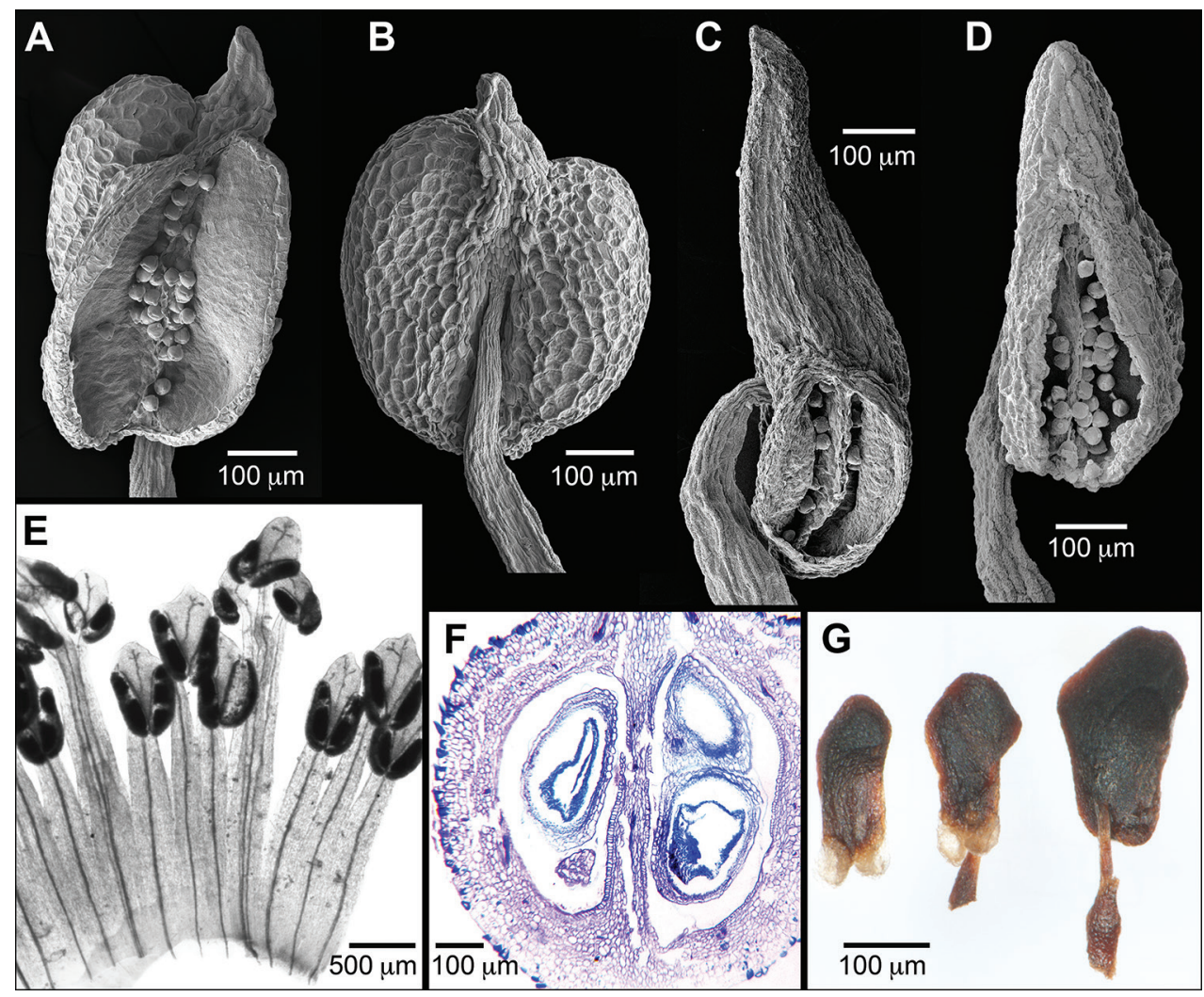

Figure 3. Stamen structure and anatomy of Humiriaceae. A Vantanea compacta anther, lateral B Vantanea compacta anther, dorsal C Vantanea depleta anther, lateral D Vantanea spiritu-sancti anther, lateral E Schistostemon oblongifolius clearing of androecium with 3 stamen types, ventral $\mathbf{F}$ Vantanea spiritu-sancti longitudinal section of ovary with 2 superposed ovules per locule; lower left ovule partial $\mathbf{G}$ Hylocarpa heterocarpa anthers (left to right): disporangiate dorsal, ventral; sterile, dorsal. Sources: A, B Hatschbach 21265 C Hammel \& Trainer 12954 D, F Silva et al. 1436 E Maas et al. 6804 G Ducke [JBRJ-30137] (all US).

\section{Extrafloral nectaries and foliar glands in Humiriaceae}

Foliar glands were found to be present on 64/65 accepted species and 22 infraspecific taxa of Humiriaceae (85 taxa examined, $100 \%$ presence; Appendix 1, Fig. 4). The remaining species not seen, recently described Vantanea maculicarpa Sabatier \& J. Engel, also has scattered abaxial glands reported (Engel and Sabatier 2018). Gland distribution ranges from relatively regular within a species, to variable between collections or even leaves on the same specimen. The two basic positional types include: (1) adaxial leaf base (basilaminar) glands as 1-3(7) more or less symmetric pairs spanning the midvein (Fig. 4B, C, F), and (2) embedded laminar glands as rows (Fig. 4A, D, J) or scattered on the abaxial (rarely also adaxial) surface (Fig. 4I). Both types of glands are circular to elliptic, sunken (especially the laminar glands) or slightly raised, have 


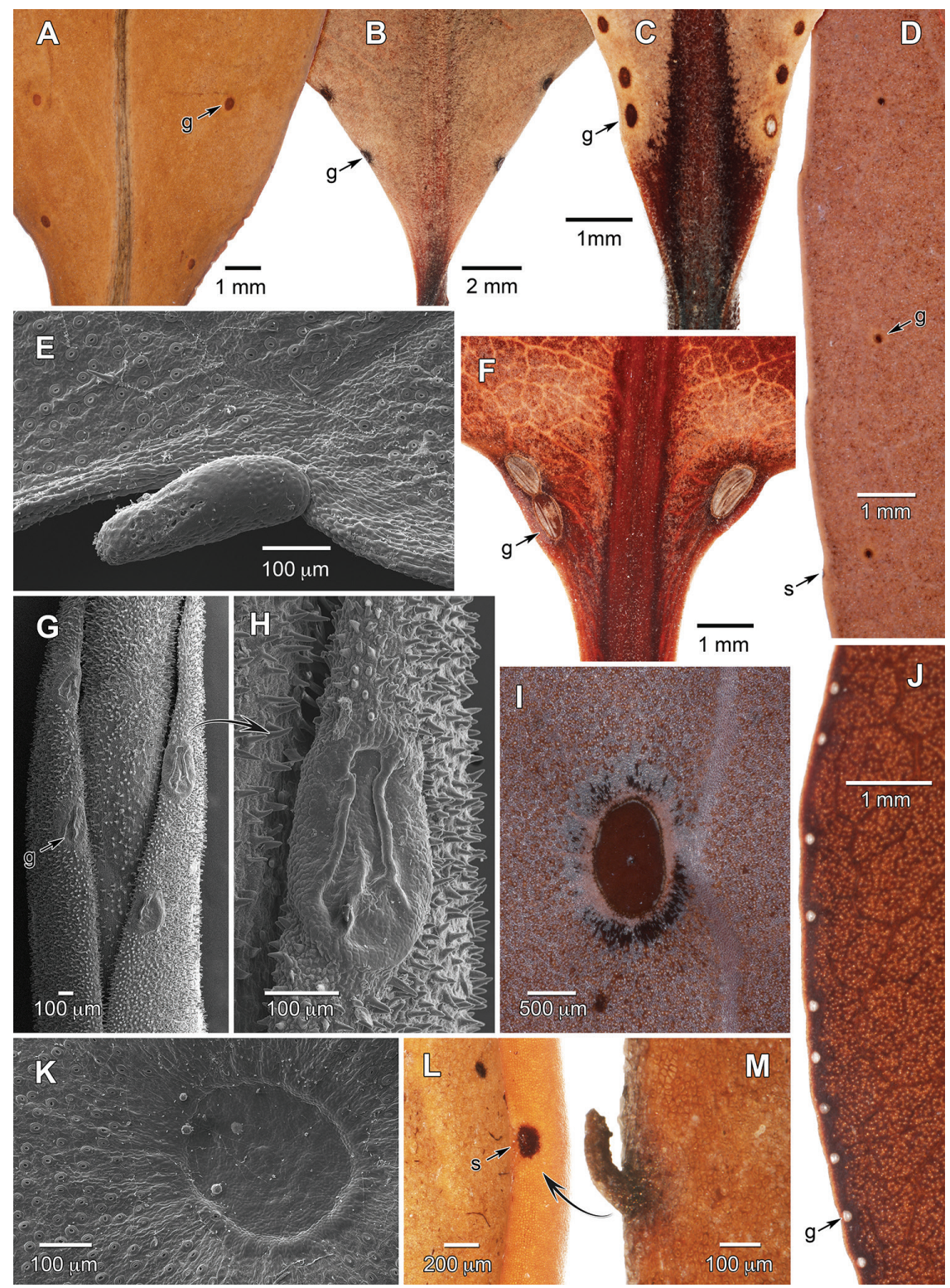

Figure 4. Extrafloral nectary and leaf margin diversity of Humiriaceae. A Vantanea depleta laminar glands, abaxial B Duckesia liesneri basilaminar glands, adaxial C Schistostemon oblongifolius basilaminar glands, adaxial D Humiriastrum ottohuberi laminar glands, abaxial E Duckesia verrucosa robust seta at margin F Sacoglottis guianensis basilaminar glands, adaxial G Humiria fruticosa shoot tip with marginal glands exposed on expanding new leaf $\mathbf{H}$ Humiria fruticosa marginal gland $\mathbf{I}$ Hylocarpa heterocarpa laminar gland, abaxial J Humiria balsamifera var. minarum dense row of marginal glands, abaxial $\mathbf{K}$ Duckesia verrucosa laminar gland, abaxial $\mathbf{L}$ Schistostemon retusus darkened scar from deciduous seta $\mathbf{M}$ Schistostemon retusus intact seta at margin. $\mathrm{g}=$ gland, $\mathrm{s}=$ seta scar. Sources: A Mori \& Kallunki 4889 B Liesner 22589 C Maas et al. 6804 D Maguire 34912 E, K Ducke 2108 F Jansen-Jacobs et al. 1898 G, H Steyermark 103255 I Ducke [JBRJ-30137] J Mexia 5815 L Redden 3372 M Cuatrecasas 7203 (all US). 
rims that are variously thickened, an outer corona free of stomata, and smooth surfaces without pores (Fig. 4H, K; 5C). In herbarium specimens the gland epidermis can be detached from the underlying gland and appear pale or whitish, which likely indicates a fluid-filled reserves pocket in the living plants (Fig. 4F, J). The extremes of gland size range from relatively large, elliptic (1.3-1.4 × 0.8-0.9 mm on Hylocarpa heterocarpa; Fig. 4I) to tiny, circular $(<0.1 \mathrm{~mm}$ diameter on Sacoglottis maguirei) structures. The laminar glands are most frequently arranged in a row near or on the margin (Fig. 4D, J) but they can also be in a row at a lesser distance from the midvein (Fig. 4A), or more rarely widely scattered. The glands away from the margins are often clearly associated with higher order veins (i.e., secondaries, intersecondaries) or otherwise intercostal. The thickened lamina often obscure higher order venation that is likely associated with intercostal glands. The glands are very sparse and/or difficult to distinguish in Duckesia and some Humiriastrum (i.e., H. melanocarpum [Cuatrec] Cuatrec., H. columbianum [Cuatrec.] Cuatrec.), and many other taxa have only a subset of gland positions (i.e., either adaxial basilaminar or abaxial laminar). For example, the scattered abaxial laminar glands in Duckesia verrucosa are only a few per specimen with most leaves lacking glands. Damage to basilaminar glands, such as appearing to be chewed, was sporadically observed and may be due to insect predation.

In Sacoglottis the paired adaxial glands usually occur near the base of the leaf blade (Fig. 4F), and details of their position, size, and shape can differ between species. The circular basilaminar glands of S. gabonensis, when present (lacking on some leaves), are unusual in appearing positionally where the first proximal teeth would be along the crenate margin. However, they lack setae associated with teeth and resemble typical basilaminar glands. The other species of Sacoglottis have basal glands (except clearly absent in S. maguirei) that are more typically basilaminar and adaxial rather than marginal. Most of the other foliar glands in Sacoglottis are tiny, in a row near the abaxial margin, and without thickened rims (Fig. 5C), although they can be variable in size, position, and number among species. Sacoglottis guianensis has considerable intra- and inter-specimen variation in the number of foliar glands. The glands of Sacoglottis maguirei are obvious on young unexpanded leaves, and then become nearly invisible small pits on mature leaves. The deciduous stipules in Sacoglottis are morphologically similar to the marginal glandular setae (Fig. 5A, E).

The leaf margins are either untoothed and entire (Humiria, Vantanea), or have glandular setae at regular intervals associated with teeth of varying degrees of prominence (remaining taxa). The non-entire margins are variously described herein (Appendix 1) and in the literature as crenate(-serrate), crenulate(-serrate), or serrate; they are rarely subentire and nearly smooth with little evidence of setae. This terminology reflects a continuum among species in the height and curvature of their small teeth. Most species have asymmetric teeth that are shallow and rounded (crenate), and more rarely have pointed projections with strongly concave distal flanks (serrate). Humiriastrum melanocarpum with leaves described as having "the margin slightly crenate with small glands" (Cuatrecasas 1961: 154) also has typical non-entire margins but more prominent darkened attachments for the setae. The setae appear deciduous in almost 

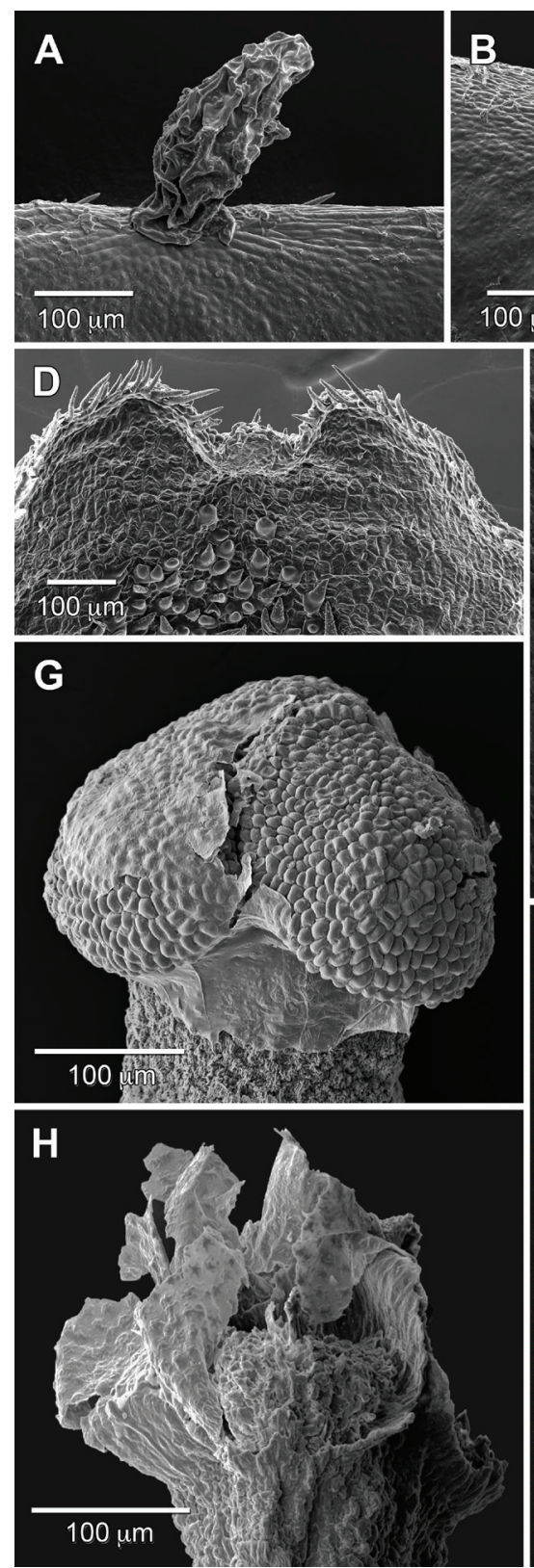
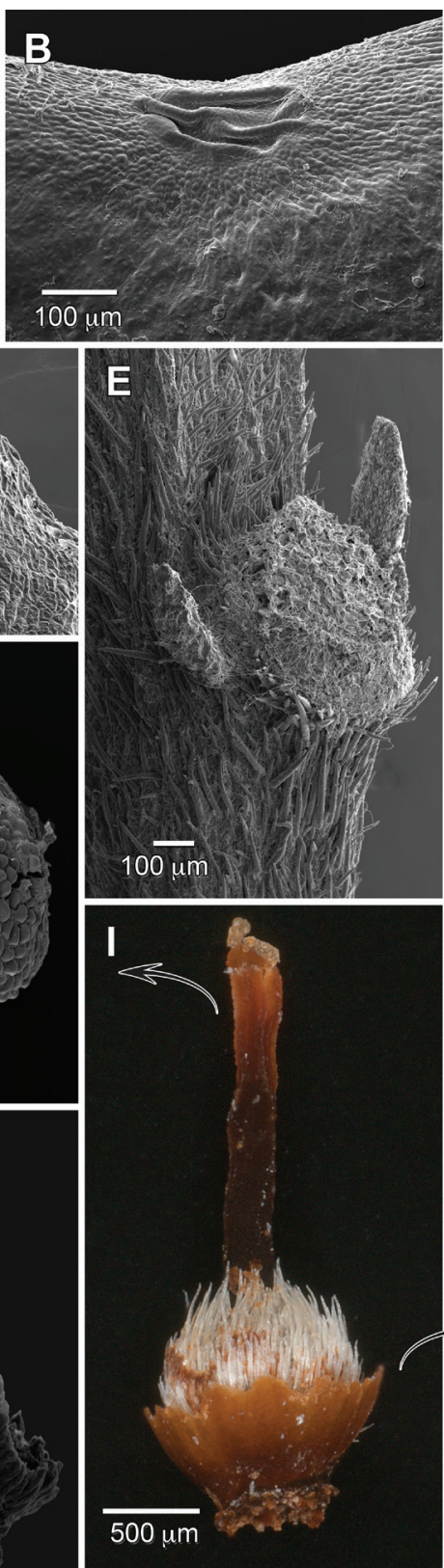
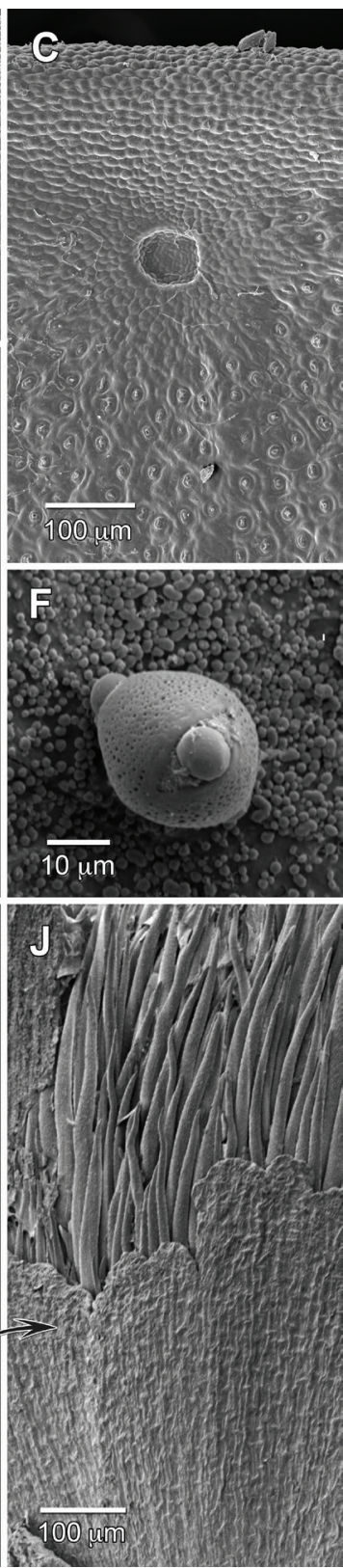

Figure 5. Micromorphology of Sacoglottis perryi. A Marginal glandular seta B basilaminar gland, adaxial C laminar gland near margin, abaxial D sepal tip, inner side with terminal gland $\mathbf{E}$ paired glandular stipules and petiole scar $\mathbf{F}$ pollen inside sporangium $\mathbf{G}$ stigma with ephemeral lobes intact and showing secretion $\mathbf{H}$ stigma lobes shredded showing thin walls $\mathbf{I}$ gynoecium with diagnostic hirsute ovary $\mathbf{J}$ glandular disc with erose margin. Sources: A-C Gillespie 2810 D-J Tripp 2984 (all US). 
all species, usually rapidly so from young expanding leaves, and leave scars with sometimes darkened, glandular-appearing points of attachment to the leaf that can be used to infer their distribution in the absence of rarely collected young leaves (Fig. 4L, M). The setae have fairly uniform morphology with modest variation in size, although those of Duckesia verrucosa are distinctive in smooth cylindrical shape which is not collapsed on drying and greater persistence (Fig. 4E). In Humiria the abaxial glands are in a (sub)marginal row, $0-0.2 \mathrm{~mm}$ from the edge, and associated with slight sinuses so as to form a margin best described as repand or slightly undulate (Fig. 4J). This distinctive margin type clearly does not have setae or associated teeth. The few glands at the leaf base of Humiria fruticosa Cuatrec. are precociously exposed (Fig. 4G) prior to full unrolling of the young leaf (supervolute-involute ptyxis), and present an aspect not seen in other Humiria taxa which otherwise all have their usually more distal marginal glands hidden in tight involute laminar rolls. The 14 varieties of Humiria balsamifera Aubl. span considerable variation in leaf features including in marginal gland density and lamina size.

\section{Taxonomic treatment}

\section{Duckesia liesneri (Cuatrec.) K.Wurdack \& C.E.Zartman, comb. nov.} urn:Isid:ipni.org:names:77198710-1

Humiriastrum liesneri Cuatrec., Phytologia 71: 165. 1991. Type: VENEZUELA. Amazonas, Depto. Rio Negro: Cerro Aracamuni, summit, Proa camp, 1400 m, 28 Oct 1987, R. Liesner \& G. Carnevali 22589 (holotype: US-3111383; isotypes: MO3641994, NY-00329209, US-3118837, VEN-277523).

Notes. When Cuatrecasas (1991) originally described Humiriastrum liesneri, he expressed uncertainty about its anther structure and relationships due to reliance on young buds for floral details. A second collection (Venezuela. Amazonas, Sierra de Unturán, 1150 m, 3 Feb 1989, Henderson 933, US), correctly annotated by Cuatrecasas as $H$. liesneri in 1994, is in flower but did not cause any classification changes for the subsequent Flora of the Venezuelan Guayana (Cuatrecasas and Huber 1999). The anther morphology of this species (Fig. 1C), with its four separate sporangia, suggests an affiliation with Duckesia or Endopleura, and the transfer here to the former is supported by more similar connective morphology, absence of disporangiate anthers, and similar small leaves (Table 1). The two species of Duckesia are otherwise very distinct from each other; fruits remain unknown for $D$. liesneri and would likely provide additional distinguishing characters. The two collections of $D$. liesneri are ca. $60 \mathrm{~km}$ apart on isolated Venezuelan tepuis near the Brazilian border and north of $D$. verrucosa, which is a lowland Brazilian species. 
Table I. Comparison of select diagnostic features for Duckesia and Endopleura.

\begin{tabular}{|c|c|c|c|}
\hline Characters & Duckesia verrucosa & Duckesia liesneri & Endopleura uchi \\
\hline Habit & Tree, $12-30 \mathrm{~m}(27-67 \mathrm{~cm} \mathrm{dbh})$ & Shrub to small tree, $2-4 \mathrm{~m}$ & Tree, (12)20-40 m (30-70 dbh) \\
\hline Leaves & $\begin{array}{c}\text { Petiole to } 1 \mathrm{~mm} \text { long; blade } \\
5.5-7.5 \times 1.7-2.3 \mathrm{~cm} \text {, } \\
\text { lanceolate, subcoriaceous; teeth } \\
\text { setae robust, to } 0.2 \mathrm{~mm} \text { long, } \\
\text { sometimes retained at maturity; } \\
\text { abaxial glands sparse, } 0-3 \text { per } \\
\text { leaf, } 2 / 3 \text { exmedial distance }\end{array}$ & $\begin{array}{l}\text { Petiole to } 2 \mathrm{~mm} \text { long; blade } \\
3.5-4.5 \times 2.2-2.7 \mathrm{~cm} \text {, elliptic } \\
\text { to obovate, coriaceous; teeth } \\
\text { setae delicate, to } 0.3 \mathrm{~mm} \text { long, } \\
\text { rapidly deciduous; abaxial } \\
\text { glands absent }\end{array}$ & $\begin{array}{l}\text { Petiole } 10-30 \mathrm{~mm} \text { long; blade } \\
17-28 \times 5.5-6.5 \mathrm{~cm} \text {, oblong to } \\
\text { narrowly elliptic, subcoriaceous; } \\
\text { teeth setae delicate, to } 0.5 \mathrm{~mm} \\
\text { long, rapidly deciduous; abaxial } \\
\text { glands in row near margin }\end{array}$ \\
\hline Inflorescence & $\begin{array}{c}\text { Axillary, small, to } 1.5 \mathrm{~cm} \text { long; } \\
\text { bracts persistent }\end{array}$ & $\begin{array}{c}\text { Axillary and subterminal, to } 2.5 \\
\mathrm{~cm} \text { long; bracts deciduous }\end{array}$ & $\begin{array}{c}\text { Axillary, to } 6.5 \mathrm{~cm} \text { long; bracts } \\
\text { persistent }\end{array}$ \\
\hline Flower & $\begin{array}{l}\text { Calyx glabrous with minutely } \\
\text { hispid margin; petals glabrous }\end{array}$ & $\begin{array}{l}\text { Calyx hispid; petals coarsely } \\
\text { hirsute }\end{array}$ & $\begin{array}{c}\text { Calyx centrally coarsely hirsute, } \\
\text { margin minutely hispid; petals } \\
\text { coarsely hirsute }\end{array}$ \\
\hline Androecium & $\begin{array}{l}\text { Filaments papillose, very } \\
\text { short-connate; anthers } 5 \\
\text { tetrasporangiate and } 15+\text { sterile }\end{array}$ & $\begin{array}{l}\text { Filaments smooth, connate } \\
\text { up to } 1 / 3 \text { length; anthers } 20 \\
\text { tetrasporangiate }\end{array}$ & $\begin{array}{l}\text { Filaments minutely papillose, } \\
\text { very short-connate; anthers } \\
10 \text { tetrasporangiate and } 10+ \\
\text { disporangiate }\end{array}$ \\
\hline Gynoecium & Pistil longer than ovary & Pistil shorter than ovary & Pistil as long as ovary \\
\hline Fruit & $\begin{array}{l}\text { Ovoid; endocarp corrugated, } \\
\text { 13+-radiate with densely packed } \\
\text { woody ribs; resinous cavities } \\
\text { small; valves conspicuous }\end{array}$ & Unknown & $\begin{array}{l}\text { Ellipsoid; endocarp star-shaped, } \\
\text { 10-radiate with } 5 \text { divided woody } \\
\text { ribs; resinous cavities absent; } \\
\text { valves inconspicuous }\end{array}$ \\
\hline $\begin{array}{l}\text { Distribution } \\
\& \text { ecology }\end{array}$ & $\begin{array}{c}\text { Brazil (Amazonas especially } \\
\text { near Manaus, Pará); 50-125 m } \\
\text { elevation, terra firme }\end{array}$ & $\begin{array}{c}\text { Venezuela (Amazonas on } \\
\text { Cerro Aracamuni and Sierra } \\
\text { de Unturán); } 1150-1400 \mathrm{~m} \\
\text { elevation, upland cloud or semi- } \\
\text { open tepui forest }\end{array}$ & $\begin{array}{l}\text { Bolivia (Pando), Brazil (Amapá, } \\
\text { Amazonas, Pará, Rhondônia) } \\
\text { Guyana, Suriname, Venezuela; } \\
\text { 50-620 m elevation, terra firme }\end{array}$ \\
\hline
\end{tabular}

\section{Vantanea spiritu-sancti (Cuatrec.) K.Wurdack \& C.E.Zartman, comb. nov.} urn:Isid:ipni.org:names:77198711-1

Humiriastrum spiritu-sancti Cuatrec., Ciencia, Mexico 23(4): 137. 1964. Type: BRAZIL. Espírito Santo, Mun. de Santa Tereza: Lombardia, 25 Jan 1954, G. Dalcolmo s.n. (holotype: RB-86212; isotype: US-2827596).

Notes. Humiriastrum spiritu-sancti was poorly known until recent ample collections allowed a fuller characterization. Giordano and Bove (2008) described its thecae as unilocular, ovary cells as uniovulate, and fruits as having five apical foramina. The transfer here to Vantanea is supported by anther structure that we interpret as two lateral bisporangiate thecae with internal septa (Fig. 3D; see Results), two superposed ovules per locule (Fig. 3F), apparent lack of foramina, as well as previously reported pollen details (Bove and Melham 2000), and preliminary molecular phylogenetic placement (Zartman et al., unpublished data). Upon examination of endocarps from Amorim et al. 1391 (US-3258470, as sectioned for Herrera et al. 2010), as well as the illustration from Giordano and Bove (2008), we could not find well-developed apical foramina that otherwise characterize Humiriastrum. Furthermore, the androecial bauplan of V. spiritusancti with a low number of alternating-length stamens is similar to that of $V$. depleta. 


\section{Sacoglottis perryi K.Wurdack \& C.E.Zartman, sp. nov.} urn:Isid:ipni.org:names:77198606-1

Figures 5-7

Diagnosis. Differs from Sacoglottis guianensis in smaller elliptic leaves, smaller shortpedunculate inflorescences with deciduous bracts, glandular sepals, hirsute ovaries, and subglobose fruits.

Type. GUYANA. Cuyuni-Mazaruni Region: Below $1^{\text {st }}$ escarpment (of four) of Kamakusa Mt., Powis Creek $\left(2^{\text {nd }}\right)$ Camp, gallery forest, $5^{\circ} 48^{\prime} 26.7^{\prime \prime} \mathrm{N}, 60^{\circ} 14^{\prime} 6.9^{\prime \prime} \mathrm{W}$, 662 m, 20 May 2012 [f], K. Redden 7264 (holotype: BRG, isotypes: K, NY, US3694797). Note: type tree of $10 \mathrm{~cm}$ dbh was cut down (Fig. 6H) during sampling and provided a wood sample (K. Wurdack, personal observation).

Description. Habit usually small tree, 6-8 m, 10-12 cm dbh (to $14 \mathrm{~m}, 50 \mathrm{~cm}$ $\mathrm{dbh}$ ), trunks lacking buttresses; bark rough, scaly, inner bark coarsely fibrous, dark brown; wood reddish-brown, diffuse porous, growth rings distinct and delimited by a fibrous zone, vessels narrow, mostly solitary, tyloses present, axial parenchyma scanty paratracheal, rays conspicuous (wood described from a $4 \mathrm{~cm}$ diam. trunk section); lateral leafy twigs $2-3 \mathrm{~mm}$ diam., puberulous, trichomes to $0.1 \mathrm{~mm}$ long. Stipules ca. 0.6 $\times 0.3$ (at base) $\mathrm{mm}$, narrowly triangular (rarely with smaller secondary lobes), thickened, glandular, rapidly deciduous. Leaves alternate, distichous on lateral branches, simple; petioles 6-10 (long) $\times 1$ (wide) $\times 0.8$ (high) $\mathrm{mm}$ mid-petiole, subterete (dorsiventrally slightly flattened), proximally slightly pulvinate, distally expanded to $2 \times$ wider with narrow wing extending from margins of lamina along shoulders of petiole, sparsely puberulous; blades $4.4-10.8 \times 1.7-4.6 \mathrm{~cm}$, length:width ratio 2.19-2.59:1 (mean $=2.37, \mathrm{SD}=0.256, n=100$ from 10 mature leaves $\times 10$ collections), oblong to ovate, base angle obtuse, base obtuse to rounded, apex angle acute, apex shape acuminate with drip tip $0.5-1.5 \mathrm{~cm}$ long, tip ending in minute apiculate glandular tooth at distal apex of midvein; subcoriaceous, abaxially sparsely puberulous, adaxially glabrous; basilaminar glands (0-1)2, usually symmetric as pair, along adaxial margin of leaf base, $0.2-0.5 \times 0.1-0.2 \mathrm{~mm}$, widely to narrowly elliptic; abaxial laminar glands sparse, up to 4 per side, $0.2-0.7 \mathrm{~mm}$ from edge, $0.1 \mathrm{~mm}$ wide, nearly circular, slightly sunken; margin shallowly crenate, darkened glandular spots in sinuses, $0.2-0.3 \mathrm{~mm}$ diam., when young these spots bearing deciduous glandular setae, $0.3 \times 0.1 \mathrm{~mm}$; dark green above and light green below in life; venation pinnate, brochidodromous; secondaries 8-9 pairs, excurrent attachment; intersecondaries frequent. Inflorescences axillary, small (shorter than leaves), <20 flowers, 3-4 orders of branching, peduncle to 1 $\mathrm{mm}$ long, rachis $5-10(20) \mathrm{mm}$ long, internal internodes successively shorter in higher order branches, to $2.5 \mathrm{~mm}$ long on secondary branches, terminal branches (pedicels) subsessile to $0.5 \mathrm{~mm}$ long; bracts $1.8 \times 1-1.5 \mathrm{~mm}$, obtuse to rounded, margin entire, sparsely puberulous, rapidly deciduous leaving joint scars. Flowers bisexual, actinomorphic, mature buds $4-4.5 \times 1.5-2 \mathrm{~mm}$; calyx cupular, sepals 5 , equal, free to base of ovary (when observed from inside), connate at base of receptacle for $1-1.5 \mathrm{~mm}$, imbricate, free portion widely rounded to minutely retuse, $1 \times 1.5 \mathrm{~mm}$, sparsely short 


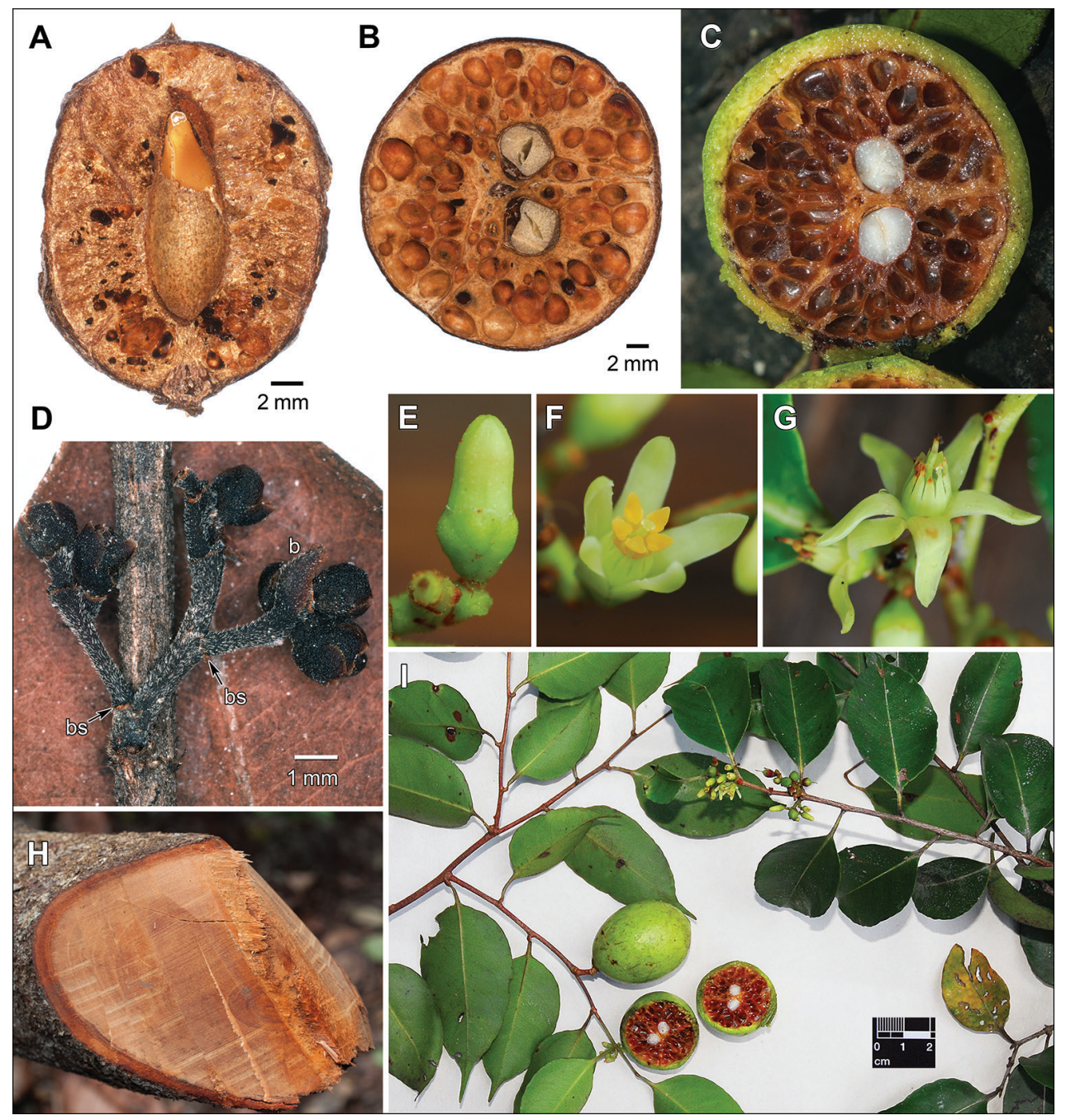

Figure 6. Macromorphology of Sacoglottis perryi. A Dried fruit with central seed embedded in woody endocarp, longitudinal split along carpel wall (dissected by Cuatrecasas) B dried fruit with 2 central seeds and endocarp lacunae, transverse section $\mathbf{C}$ fresh fruit with fleshy yellow-green exocarp and liquid in endocarp lacunae, transverse section $\mathbf{D}$ young inflorescence with bracts intact (b) or fallen leaving bract scars (bs) $\mathbf{E}$ mature bud with marginal sepal gland (small red dot in center) $\mathbf{F}$ partly open flower with intact anthers $\mathbf{G}$ post-anthetic flower $\mathbf{H}$ freshly cut trunk $\mathbf{I}$ type in life just before pressing. Sources: A Gillespie 2810 B Tripp 2984 C, E-I Redden 7264 D Hoffman 1600 (all US).

puberulent (trichomes shorter than elsewhere on plant) inside and out, margin finely ciliate, hyaline, usually with single gland ca. $0.1 \mathrm{~mm}$ diam. at minutely retuse apex, in life sepals green and gland red; petals 5, free, $4-4.5 \times 1 \mathrm{~mm}$, oblong-lanceolate, tip acute, thick with narrow hyaline entire margin, glabrous, aestivation quincuncial, greenish-white in life and reflexed at anthesis; stamens 10, glabrous, stiffly erect in bud 
and at anthesis, dimorphic, alternating in 2 lengths; 5 antesepalous longer, filaments 3.5-3.6 mm long; 5 antepetalous shorter, filaments $3 \mathrm{~mm}$ long; filaments of both lengths subulate, complanate, basally connate to $1.5 \mathrm{~mm}$ and tips free, $0.3-0.5 \mathrm{~mm}$ wide at start of free portion $x<0.1 \mathrm{~mm}$ thick, in life greenish-white; anthers slightly dimorphic and differing in length of connective apex due to tight packing in bud which prevents full development of shorter anthers, antesepalous $0.8-0.9 \times 0.5 \mathrm{~mm}$, antepetalous $0.6-0.7 \times 0.5 \mathrm{~mm}$, dorsifixed; connective thickened, apical tip acute, base $\mathrm{V}$-shaped and forcing pollen sacs to slightly diverge distally; pollen sacs 2 per anther (disporangiate), ca. $0.3 \mathrm{~mm}$ long, in proximal half of anther, stomium narrowly elliptic, covered by valve with a thin dorsal hinge and opening with a ventral lip, yellow-orange in life; ovary 1-1.2 × 1.2-1.3 mm, subglobose, densely hirsute with long trichomes to $0.5 \mathrm{~mm}$; disc $0.5-0.6 \mathrm{~mm}$ high, thin, cupular, margin erose with rounded irregular lobes to $0.1 \mathrm{~mm}$ high; style $2-2.5 \times 0.3 \mathrm{~mm}$, single, columnar, with distinct discontinuity and slightly thinner for distal $1 / 3$, glabrous; stigma minutely 5 lobate-capitate. Infructescence: 1-2 fruits maturing per inflorescence; fruit stalk 5-8 $\times$ 1 (diam.) $\mathrm{mm}$, consisting of pedicel and 1-2 inflorescence nodes; petals and anthers caducous, sepals and filaments persistent, filaments forming protective palisade-like sheath around young developing fruit, stigmas and distal thinner part of style senescing rapidly. Fruit drupaceous, 33-35 × 23-30 mm (nearly mature, but ultimate size unknown), length:width ratio 1.07-1.44:1 (mean $=1.23, \mathrm{SD}=0.107, n=19$ from 9 collections, excluding McDowell 2993), sub-globose to ellipsoid, tip short apiculate, glabrescent but sparse trichomes remaining at apex, surface smooth when fresh, when dry sometimes slightly dimpled due to underlying endocarp, exocarp $0.5-1 \mathrm{~mm}$ thick; endocarp woody, obscurely bullate on surface due to underlying lacunae, with 3 slight longitudinal furrows, brown, interior with numerous lacunae; lacunae 1.5-5 $\times 1-4 \mathrm{~mm}$, asymmetric ellipsoidal, greatly varying in size and exact shape within a fruit, in life filled with watery light brown fluid that dries to form thin dark brown, glassy, resinous layer; walls between lacunae $<0.05 \mathrm{~mm}$ (translucent) $-0.5 \mathrm{~mm}$, grading thicker at vertices between multiple lacunae, distinctly thickened around seeds (locule cavity wall) and along the indistinct carpel sutures; locule snug around seed. Seeds 1-3 per fruit, 15 (long) $\times$ 5-6 (deep; parallel to embryo) $\times$ 4-5 (wide; perpendicular to embryo) $\mathrm{mm}$, oblong, (sub)circular in transverse section, proximal end rounded, distal (hilar) end attenuate; coat thin, papery, brown; endosperm copious, fleshy, oily.

Etymology. The specific epithet commemorates Claudius Perry (1977-2011; Kelloff et al. 2011: plate 2A), a Wapishana Amerindian originally from Marunawa, who planned to be on the type-collecting trip but tragically perished on 14 Jun 2011 when a portion of his home on the Dadanawa Ranch collapsed during a storm. Although by trade a vaquero (cowboy) in the Rupununi savanna region of southern Guyana, he also served as a parataxonomist and guide on many plant and animal research expeditions (1996-2010) across Guyana. He was especially valued in the many botanical expeditions lead by H. David Clarke (Kelloff et al. 2011), Karen Redden, and the second author. He accompanied both authors herein, had a keen eye for plant diversity, and was a highly skilled collector, especially of trees that he enjoyed rapidly climbing with 
spikes. He participated in expeditions that yielded the paratype collections of Forbes 325 and Redden 6582, and personally gathered the latter.

Distribution and ecology. Sacoglottis perryi is apparently confined to the Pakaraima Mountains of Guyana, and most localities are along mid-elevation (500-800 m) primary and secondary creeks in the headwaters of the Mazaruni River basin. It should be expected in other upland areas of the Mazaruni watershed including in adjacent Venezuela and perhaps Brazil. The tree typically grows in gallery forests at the edge of those waterways, or in forest patches in the white-sand savanna/forest mosaics of the region. Flowering occurs in May-June, with the fruits slowly developing over the course of a year. The timing of fruit ripening, likely in the fall, and features of the ripe fruit are unclear. The Kamakusa collections with the largest fruits on any specimens were hard and green when fresh (Fig. 6I; K. Wurdack, personal observation). In other species (e.g., S. guianensis; see Holanda 2013) the exocarp turns from green to deep orange, reddish, or brown, and can be fleshy and sweet. The fruits of Sacoglottis spp. are buoyant, leading to long distance transport by water (e.g., as ocean drift); they have also been documented to be dispersed by bats (Lobova et al. 2009) and monkeys (van Roosmalen 1985). The accessible position of the fruit of $S$. perryi on thin, pendulous, distichous-leaved branchlets over small waterway corridors appears advantageous for both bat and water dispersal.

Additional collections examined. GUYANA. Cuyuni-Mazaruni Region: Imbaimadai, Partang River along riverbank past first rapids NE of base camp, 05ㄴ' $10.5^{\prime \prime N}, 60^{\circ} 16^{\prime} 50.1^{\prime \prime W}, 873$ m, 2 Dec 2002 [fr], Forbes 325 (US); Maipuri Falls, Karowrieng River, 05\%41'N, 60¹4'W, 570-600 m, 20 Dec 1989 [fr], Gillespie 2810 (US); Imbaimadai Creek, $1 \mathrm{~km}$ W of Imbaimadai, $05^{\circ} 42^{\prime} \mathrm{N}, 60^{\circ} 18^{\prime} \mathrm{W}, 500 \mathrm{~m}, 16$ May 1992 [fl, fr], Hoffman 1600 (NY, US); basecamp $8.6 \mathrm{~km}$ NE [of] Imbaimadai on Partang River tributary, 0.75 km E, 0546'N, 60¹5'W, 625 m, 20 May 1992 [fl, fr], Hoffman 1745 (MO, NY, US); basecamp $8.6 \mathrm{~km}$ NE Imbaimadai on Partang River

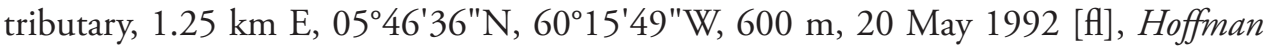
1755 (MO, NY, US); Mt. Aymatoi (sandstone), 0555'N, 61 W, $1150 \mathrm{~m}, 16$ Oct 1981 [fr], Maas et al. 5753 (MO, US); Imbaimadai Savannas, Upper Mazaruni River, 24 Oct 1951 [fr], Maguire \& Fanshawe 32250 (MO, NY); Sagaraimadai Savanna, Upper Mazaruni River, 16 Nov. 1951 [fr], Maguire \& Fanshawe 32619 (MO, NY); from Utshe River to Great Falls on Kamarang River, 4-5 km SE of Utshe camp, 05\%43'N, 6107'W, 850-975 m, 26 May 1990 [f], McDowell 2920 (MO, NY, US); 7 km N of Paruima Village, after descent from south face of Mt. Waleliwatipu, $05^{\circ} 54^{\prime} \mathrm{N}, 61^{\circ} 02^{\prime} \mathrm{W}$, 980-1060 m, 30 May 1990 [f, fr], McDowell 2993 (MO, NY, US-2 sheets); to plateau [at] S end of Haiamatipu, $05^{\circ} 28^{\prime} \mathrm{N}, 60^{\circ} 32^{\prime} \mathrm{W}, 610-914 \mathrm{~m}, 20$ Jun 1991 [f], McDowell 4734 (NY, US); Imbaimadai Creek, W of Imbaimadai, $05^{\circ} 42^{\prime} \mathrm{N}, 60^{\circ} 18^{\prime} \mathrm{W}, 503 \mathrm{~m}, 22$ Jun 1986 [fr], Pipoly 7990 (MO, NY, US); Vicinity of Chinoweing Village, 5³2'N, 6007'W, 650-670 m, 21 Feb 1987 [fr], Pipoly 10484 (NY-2 sheets, US); Imbaimadai, Karowrieng River, towards waterfall $2.32 \mathrm{mi}$ E of Base Camp 1, bordering Karowrieng Creek, 540'42.4"N, 60¹4'30.8"W, 575 m, 22 Jan 2004 [fr], Redden 1489 (US); Mazaruni River, just above ABC Falls, trail/track $2.03 \mathrm{mi}$ SW of Base Camp 6 heading 


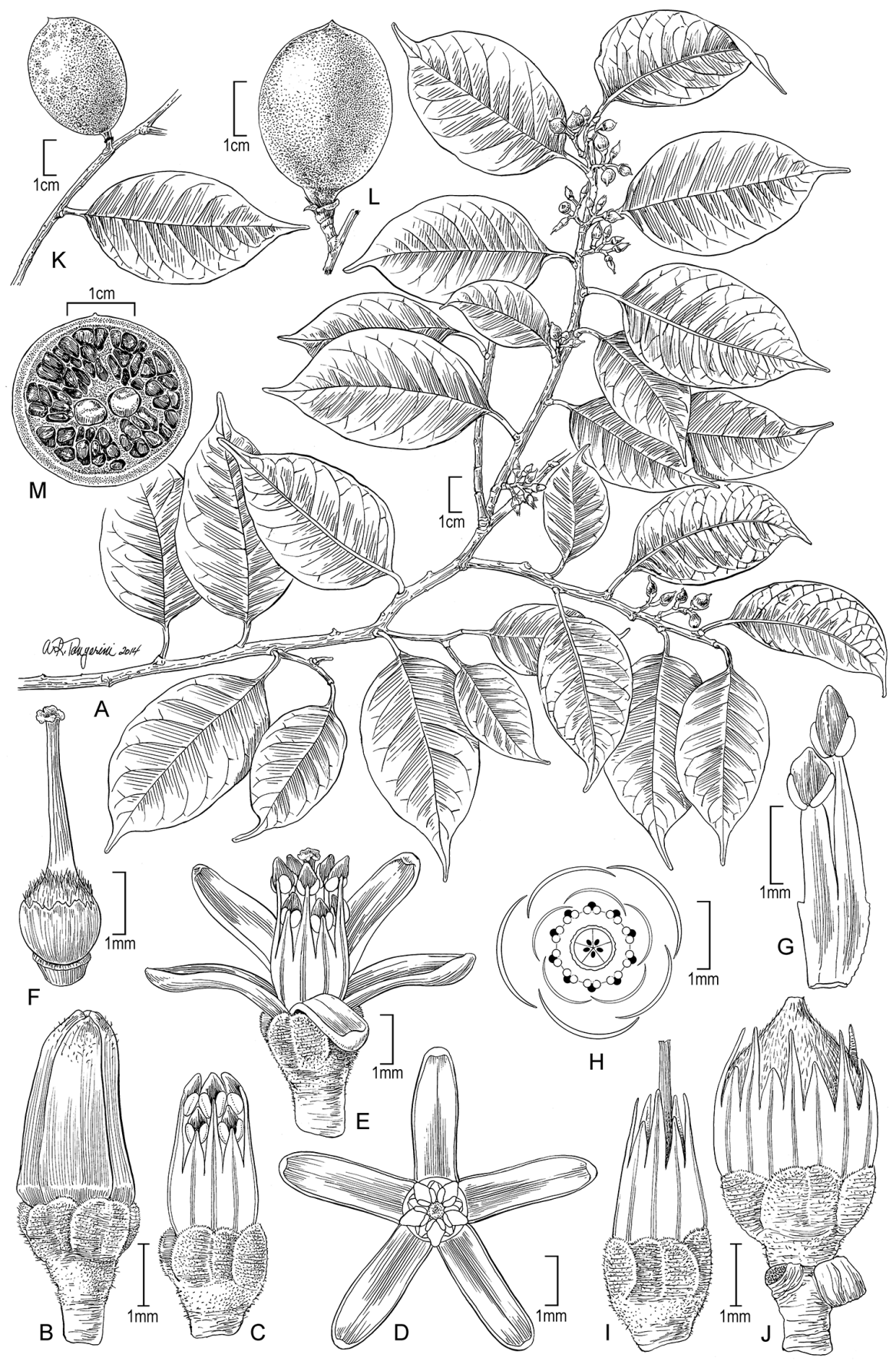

Figure 7. Illustration of Sacoglottis perryi. A Habit B bud C bud with petals removed D open flower, axial $\mathbf{E}$ open flower, lateral $\mathbf{F}$ gynoecium $\mathbf{G}$ stamen cluster of 2 types, ventral $\mathbf{H}$ floral diagram $\mathbf{I}$ postanthetic flower $\mathbf{J}$ young fruit $\mathbf{K}, \mathbf{L}$ fruit $\mathbf{M}$ fruit with 2 central seeds and endocarp lacunae, transverse section. Source: A-M from specimens and life photos of Redden 7264 (US). 
E, 64'25.2"N, 60³9'14.3"W, 605 m, 19 Feb 2004 [young fr], Redden 2008 (US); Kako River, top of waterfall, $05^{\circ} 28^{\prime} 50.8^{\prime \prime N}$, 60 50'49.3"W, 687 m, 15 May 2009 [fl, fr], Redden 6582 (US); below $1^{\text {st }}$ escarpment (of four) of Kamakusa Mt., Powis $\left(2^{\text {nd }}\right.$ ) Camp and vicinity, along creek bank at camp 5०48'34.6"N, 60¹4'21.5"W, $651 \mathrm{~m}, 21$ May 2012 [Al, fr], Tripp 2984 (US); Kako River, gallery forest near rapids, $05^{\circ} 30^{\prime} 27^{\prime \prime N}$, 6050'30.3"W, 505 m, 10 May 2009 [f], Wurdack 4911 (US); below $1^{\text {st }}$ escarpment (of four) of Kamakusa Mt., Powis $\left(2^{\text {nd }}\right)$ Camp and vicinity, along creek bank at camp $5^{\circ} 48^{\prime} 34.6 " \mathrm{~N}, 60^{\circ} 14^{\prime} 21.5^{\prime \prime W}, 651 \mathrm{~m}, 13$ Jun 2012 [young fr], Wurdack 5898 (US).

\section{Discussion}

Sacoglottis, and delimitation and morphology of newly described S. perryi

The 11 species of Sacoglottis are compared in Table 2 (gland details in Appendix 1), which highlights important diagnostic characters such as inflorescence structure (peduncle and bracts), sepal glands, ovary vestiture, and fruit shape. Especially significant is the densely hirsute ovary, a feature that only occurs in S. perryi (Fig. 5I) and Central American $S$. trichogyna Cuatrec. All other species in the genus have glabrous ovaries. Besides ovary vestiture, no other aspect of morphology suggests a closer relationship between $S$. perryi and S. trichogyna, and their fruit structures are very different (Herrera et al. 2010: fig. $2 \mathrm{~N}$ ). The leaves of $S$. perryi are the second smallest in the genus after diminutive $S$. maguirei, and have a very pronounced drip tip and an shallowly crenate margin (Fig. 6I, 7A). Sacoglottis perryi possesses the full suite of glandular structures known for the family, including small abaxial and basilaminar glands, rapidly deciduous marginal setae, thickened stipules similar to the setae, gland-tipped sepals, a floral disc, and thickened connectives (Fig. 5A-E, J). The minute stigmas appear to secrete and consist of five hollow (presumably fluid-filled in life) thin-walled lobes that rapidly degrade atop a sturdy, persistent style (Fig. 5G, H). This unusual morphology appears typical for the genus and the family in general. The small, subspheroidal, tricolporate, microreticulate pollen of $S$. perryi (Fig. 5F) resembles that of other species in the genus (see Bove and Melhem 2000). Four species of Sacoglottis are now known from Guyana including S. amazonica Mart., S. cydonioides Cuatrec., S. guianensis, and $S$. perryi. The fruit shape of $S$. perryi is subglobose and intermediate between globose $S$. cydonioides and more elongate $S$. amazonica and S. guianensis. The fruits of McDowell 2993 are more elongate (length:width ratio $1.37-1.63: 1$, mean $=1.47, \mathrm{SD}=0.108, n=4$ ) than those typical for $S$. perryi, but in other characters the collection agrees with the species. The endocarp morphology of S. perryi does not resemble that of a putatively undescribed Sacoglottis only known from well-weathered ocean drift endocarps (van der Ham et al. 2015).

The biogeography of Sacoglottis includes disjunctions with clear long-distance dispersal to Africa for S. gabonensis and to Isla del Coco far off the Pacific coast of Costa Rica for endemic $S$. holdridgei Cuatrec., and there is direct evidence of contemporary and fossil sea drift (Herrera et al. 2012, 2014; van der Ham et al. 2015). Mostly 


\begin{tabular}{|c|c|c|c|c|c|c|c|c|c|}
\hline $\mid$ & 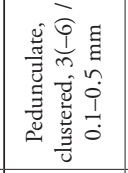 & 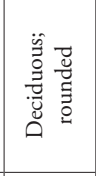 & 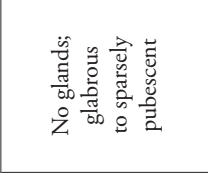 & 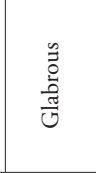 & 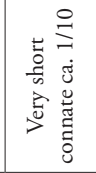 & 总 & 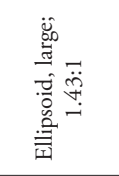 & 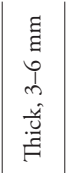 & 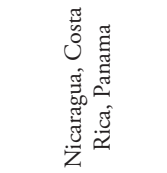 \\
\hline है है & 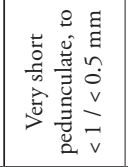 & 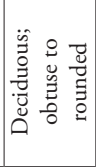 & 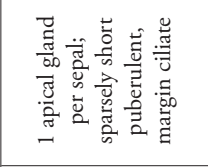 & 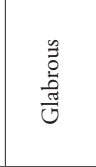 & 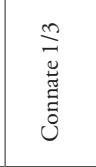 & 总 & 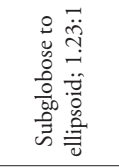 & 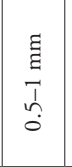 & 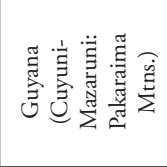 \\
\hline : & 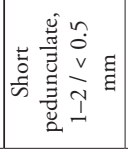 & 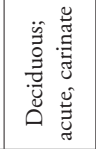 & 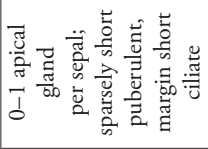 & 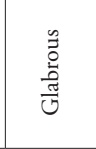 & $\begin{array}{l}\stackrel{5}{\Sigma} \\
\tilde{y} \\
\tilde{0} \\
0 \\
0\end{array}$ & 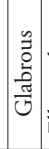 & 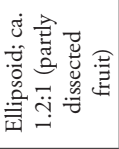 & 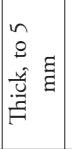 & 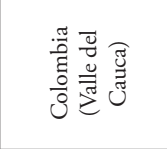 \\
\hline $\mid$ & 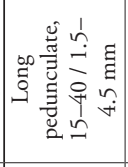 & 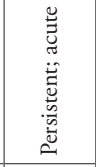 & 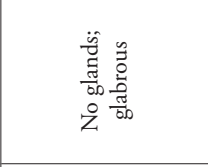 & 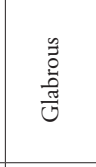 & 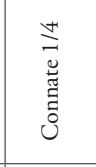 & 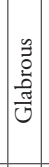 & 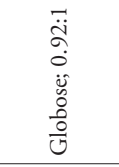 & 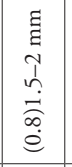 & 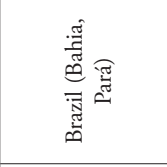 \\
\hline : & 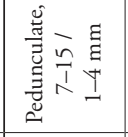 & 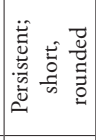 & 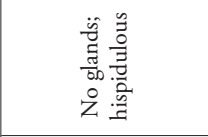 & 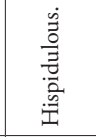 & 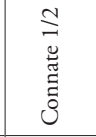 & 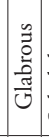 & 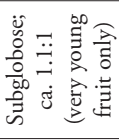 & $\begin{array}{l}5 \\
0 \\
0 \\
5 \\
5\end{array}$ & 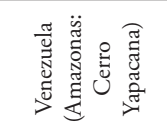 \\
\hline $\mid$ & 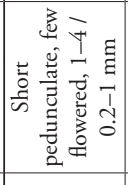 & 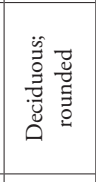 & 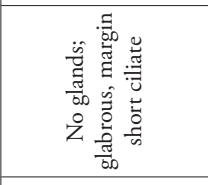 & 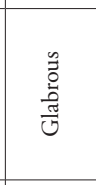 & 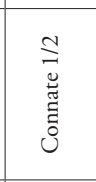 & 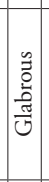 & 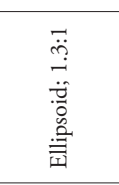 & 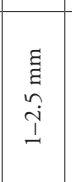 & 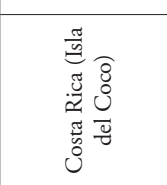 \\
\hline 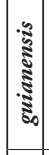 & 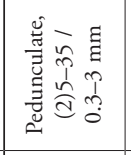 & 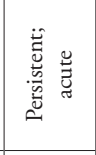 & 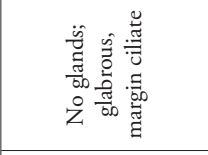 & 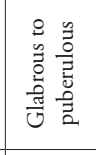 & 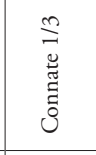 & 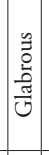 & 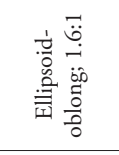 & 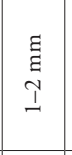 & 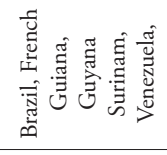 \\
\hline 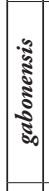 & 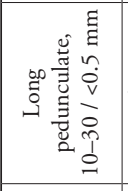 & 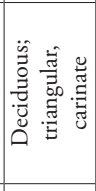 & 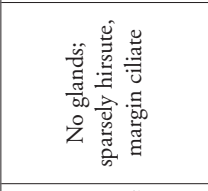 & 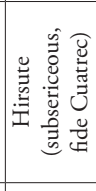 & 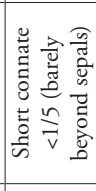 & $\frac{a}{0}$ & 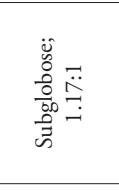 & 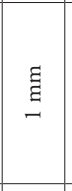 & 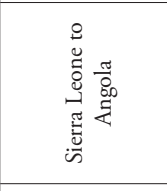 \\
\hline 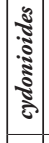 & 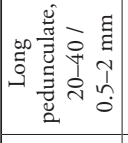 & 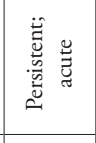 & 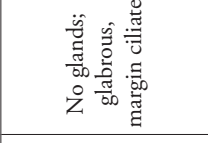 & 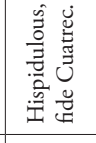 & 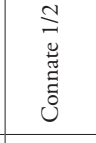 & 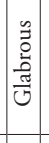 & 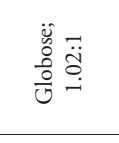 & $\begin{array}{l}\text { E } \\
\text { I } \\
\text { I }\end{array}$ & 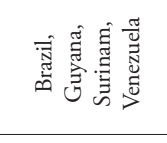 \\
\hline $\mid$ & 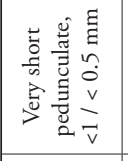 & 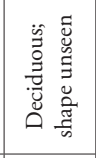 & 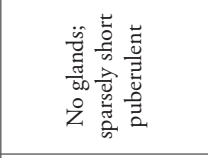 & 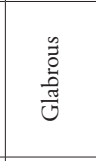 & 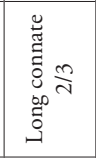 & 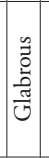 & 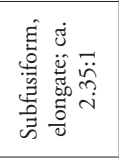 & 吉 & 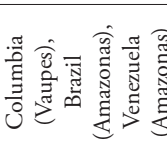 \\
\hline 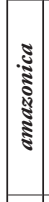 & 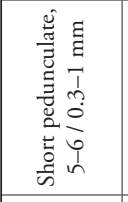 & 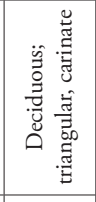 & 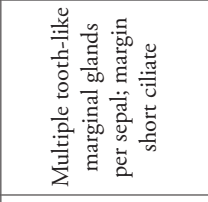 & 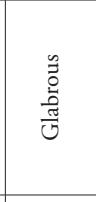 & 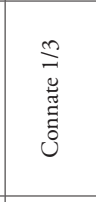 & 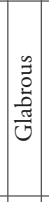 & 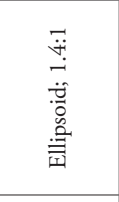 & 表 & 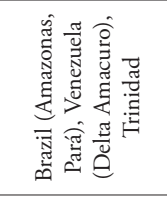 \\
\hline $\mid$ & 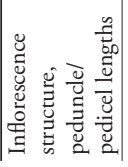 & 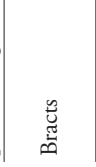 & 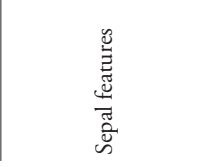 & 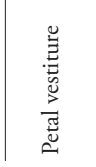 & 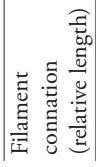 & 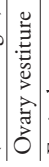 & 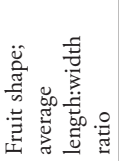 & 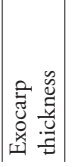 & 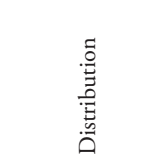 \\
\hline
\end{tabular}


Amazonian Sacoglottis amazonica occurs in Delta Amacuro, Venezuela and reaches the nearby island of Trinidad. Otherwise the genus and indeed the entire family oddly lack a West Indian presence (Acevedo-Rodríguez and Strong 2012). Sacoglottis perryi is geographically relatively isolated from other species in the genus. It only overlaps with S. guianensis based on a single collection (Gillespie 2939, US) from the vicinity of Imbaimadai that has typical elongate fruit and a long-pedunculate inflorescence. Otherwise, S. guianensis occurs further south in the Essequibo River watershed (i.e., southern Pakaraima Mountains and Acari Mountains on the border with Brazil) and is broadly distributed elsewhere in northern South America. We reexamined the identity of the Schomburgk brothers' collections of S. guianensis ([Rob.] Schomburgk, $2^{\text {nd }}$ ser. 571 but likely mistranscribed for 574, P; 574, F, G, NY, P; Rich. Schomburgk 842, F image ex B, US) from Guyana, as they collected in or near the Pakaraima Mountains, and the lectotype, Schomburgk 574 (Cuatrecasas 1961), is from "Roraima" at the drainage divide of the Mazaruni watershed. All of these specimens have long-pedunculate inflorescences and cannot be confused with $S$. perryi. The Schomburgk expedition routes, including the approach to Mt. Roraima, skirt around the Mazaruni headwaters and were not within the presently known range of $S$. perryi (Roth 1923, van Dam 2002). A sterile collection (Guppy 308, NY) from southern Guyana, attributed by Cuatrecasas (1961) to S. amazonica, appears based on leaf similarities to be S. guianensis. The Humiriaceae of Guyana now totals six genera and 13 species (Funk et al. 2007).

The significance of inflorescence structure variation in Sacoglottis has not been previously emphasized, although it is implicit in details of the descriptions and key of Cuatrecasas (1961). His first species-key couplet relates to deciduous versus persistent bract condition, which appears correlated with other aspects of inflorescence architecture. Taxa with persistent bracts have long-peduncled, often large inflorescences, while those with deciduous bracts have short to non-existent (giving the appearance of multiple inflorescences per leaf axil) peduncles and generally smaller inflorescences. The deciduous bracts are rapidly lost, and bract morphology can be hard to document without very young inflorescences. An exception to this inflorescence structure dichotomy is Sacoglottis gabonensis, which has deciduous bracts and a long pedunculate (1-3 $\mathrm{cm}$ ) inflorescence. Sacoglottis maguirei, a tepui endemic known only from the type collection (Maguire et al. 30693), has been mischaracterized as deciduous (Cuatrecasas 1961), but possesses previously overlooked very short, persistent bracts that are consistent with its long-peduncled inflorescence architecture. The bract condition for the other genera of Humiriaceae is persistent (Endopleura, Humiria, Hylocarpa), deciduous (Vantanea), or mixed (Duckesia, Humiriastrum, Schistostemon).

Schistostemon, presently containing nine species, was formerly a subgenus or section of Sacoglottis and elevated to a genus principally based on differences in androecial structure with a doubling of stamen number to 20, an increase to 30 anthers, and three stamen types instead of two (Cuatrecasas 1961). Of particular note in differentiating Schistostemon are the antesepalous longest stamens that are trifurcate at their apex to support three anthers per stamen (Fig. 2G, 3E). An overlooked difference between the genera is in pistil morphology, which is thin and as long or longer than the stamens in 
Sacoglottis, but in Schistostemon is stout and shorter than the stamens. Fruit and vegetative details are otherwise strikingly similar between the genera. The renewed suggestion by Herrera et al. (2010) of returning to a broader, pre-Cuatrecasas circumscription of the Sacoglottis-Schistostemon group (i.e., Sacoglottis s.l.) needs further study within the framework of a well-sampled molecular phylogenetic analysis that includes taxa with both types of inflorescence structure. Limited molecular phylogenetic evidence has indicated that Schistostemon is not monophyletic and embedded within a paraphyletic Sacoglottis (Bardon 2015).

\section{Broader significance of androecial structure in Humiriaceae}

Humiriaceae share stamens partly connate, filaments subulate and complanate, and anthers that are dorsifixed, versatile, caducous, lacking stomata, and possessing connective protrusions. Most of these shared androecial features are broadly distributed, even in combination, across the rosids (Endress and Stumpf 1991). The eight genera presently can be clearly defined based on details of androecial structure including number and morphology of both stamens and sporangia, although ovule number and endocarp structure are also important distinguishing generic characters. Our observations on gross androecial structure largely agree with and complement prior floral anatomy studies by Narayana and Rao (1969-1977). Variations in anther sporangium morphology are especially interesting from an evolutionary perspective in Humiriaceae due to transitions among the three distinct forms which include, (1) tetrasporangiatedithecal with two lateral disporangiate thecae, a typical rosid anther configuration, in Vantanea, (2) tetrasporangiate-tetrathecal with four monosporangiate thecae arranged as two superposed pairs in Duckesia and Endopleura, and (3) disporangiate-dithecal with two monosporangiate thecae arranged as one pair in the remaining five genera. Disporangiate anthers characterize some families of rosids (e.g., Cucurbitaceae, Malvaceae), but are otherwise very sparse in Malpighiales (e.g., cleistogamous flowers of Viola, Violaceae; Endress and Stumpf 1991) except for Humiriaceae.

Vantanea has long been considered the most ancestral genus of Humiriaceae based on androecial structure (Cuatrecasas 1961, Narayana and Rao 1969, 1977, Herrera 2010, Kubitzki 2014), although molecular phylogenetic evidence suggests a nested placement (Bardon 2015). A complex interpretation by Narayana and Rao (1976a, b, 1977) on the origin of the disporangiate anthers based on the position of the sporangia relative to the enlarged connective in bud transverse sections posits that in Humiria and Schistostemon the dorsal (outer) sporangia were lost, while in Humiriastrum and Sacoglottis the ventral (inner) sporangia were lost. We observed the anthers of Sacoglottis and Schistostemon to be nearly indistinguishable when finely comparing anthers of the same type and did not find any transverse shifts in sporangial position to suggest differing origins. Moreover, anther similarities in regard to sporangial position and dehiscence lines extend across all the disporangiate genera (in part for Humiriastrum), although differences exist in connective details. Humiriastrum is now more homogeneous 
with our generic transfers (i.e., Duckesia liesneri and Vantanea spiritu-sancti); however, the remaining species have two different thecal orientations, which could correspond to different origins (i.e., from dorsal or ventral sporangia). While $H$. dentatum and $H$. glaziovii in particular differ from the rest in regard to orientation, by other morphological bases they firmly belong to Humiriastrum and it is premature to reconsider generic affiliation. Whether the disporangiate bauplan has one or more origins needs further testing with floral development and phylogenetic studies. The superposed pairs of sporangia (tetrasporangiate-tetrathecal) in Duckesia and Endopleura have been thought to represent an intermediate state in the transition from tetrasporangiate-dithecal to disporangiate-dithecal anthers (Cuatrecasas 1961). Moreover, they establish homologies and clearly show that the ventral sporangia can assume a basal position with distalproximal dehiscence. Some phylogenetic evidence has indicated those genera may be embedded within a disporangiate clade and may not be sister groups (see Herrera et al. 2010, Bardon 2015), although we found no major morphological differences to contradict a single origin of the superposed-sporangia anther type. The disporangiate and superposed-sporangia anthers of Humiriaceae, sometimes described as "dehiscing by detachment" (Cuatrecasas 1961, Kubitzki 2014), have markedly eccentric stomia that fit modern definitions of valvate and have similarities in dehiscence lines to established valvate taxa such as Hamamelis L. and Grubbia P.J. Bergius (Hufford and Endress 1989, Endress and Stumpf 1990). Their fundamentally valvate nature has not been noted in prior broad comparative anther surveys and apparently does not occur in any other rosid (see Endress and Stumpf 1990, 1991).

Disporangiate-dithecal anthers are often correlated with specialized floral biology, which can be enabled by restrictive anther openings such as valves (Endress and Stumpf 1990). The pollination biology of Humiriaceae has been only carefully studied for Humiria balsamifera (Holanda et al. 2015), and indicated bee pollination of its nectariferous flowers. For the valvate taxa (i.e., all except Vantanea), further study is needed to see if the anther valves constrain pollen release. The greatest floral variation (i.e., perianth size, stamen number and length, color) occurs in Vantanea with its relatively unspecialized anthers. Vantanea guianensis in particular with its showy red flowers in large clusters is likely hummingbird pollinated and recorded as visited by hummingbirds by Gentry \& Stein 46932 (US). However, it differs from typical flowers with that pollination syndrome in not being especially tubular in nature with spreading $30-40 \mathrm{~mm}$ long petals, which are shed early before the androecium, and stamen connation for only 5-7 $\mathrm{mm}$ of their $25-35 \mathrm{~mm}$ length. Variable morphological features that likely affect pollination biology and need further investigation in an evolutionary framework include flower color (white to greenish or red to pink), disc morphology (cupular to variously dissected), filament ornamentation (papillose to smooth), stamen length (long and thin to short and robust), stamen number (10-200+), staminodes (presence or absence), stamen connation (nearly free to half connate), anther ornamentation (hairs or connective elaborations), and mode of dehiscence (longitudinal slits or valvate). Most taxa have elaborated and likely glandular connectives and discs. 
Stamen connation can affect pollinator nectar access by forming a tube around the disc that varies in height among genera and species (e.g., Sacoglottis spp., Table 2), although nectar robbing by piercing the tube is known for Humiria (Holanda et al. 2015). Anthesis is likely generally of short duration based on the morphology patterns of versatile, caducous anthers and delicate stigmas, although this has been directly little studied (Holanda et al. 2015).

\section{Extrafloral nectaries of Humiriaceae}

We documented EFNs in all species of Humiriaceae, and found distributional and morphological differences. Some of these differences appear informative at the generic level, including the marginal glands of Humiria, entire eglandular margins of Vantanea, and the exceptionally large laminar glands of Hylocarpa. Our EFN survey, although mostly qualitative in nature, also reveals that their species-level taxonomic value is limited due to high variation in abundance and position, and low intra-specific morphological variation. The EFN ubiquity indicates that they are phylogenetically conserved (i.e., plesiomorphic) for the family, and is a conclusion that differs greatly from character reconstructions that could be hypothesized under the prior understanding of their taxonomic distribution in only three species. This conclusion is also important when considering EFN evolution in the broader context of Malpighiales where they have been documented in 13/39 families (Weber and Keeler 2013), and when considering correlations between EFNs and higher lineage diversification rates (Marazzi and Sanderson 2010, Weber and Agrawal 2014). Humiriaceae contains relatively low extant species-richness despite EFN richness. The gross morphology and variation of Humiriaceae EFNs are consistent with reports from other families (e.g., Tilney and van Wyk 2004, Marazzi et al. 2012, Gonçalves-Souza et al. 2016), although the glands appear unremarkable with no specialized pores or unusual locations on the plants. The shallow teeth forming the crenations along the leaf margins of Sacoglottis gabonensis have been studied in detail, and on the young leaves were found to secrete nectar that attracts ants (Belin-Depoux 1993). Belin-Depoux (1993) did not comment on the basilaminar glands, which we found to be relatively easy to overlook and confuse with the marginal setae scars (see Results). The glands along the leaf margins of Humiria differ from those elsewhere in the family in their position as an often dense submarginal row. They are not modified teeth or setae, which are lacking, but appear to be typical laminar glands developmentally shifted to the margin. Humiria spp. are largely savanna dwellers unlike most of the other Humiriaceae taxa in forests, and habitat shifts may have influenced their EFN evolution. Such habitat shifts have been implicated in leaf defense adaptive evolution, including decrease in EFN abundance and increase in glandular trichomes in neotropical Bignoniaceae (Nogueira et al. 2012). In addition to the extrinsic defenses conferred with the glands, Humiriaceae leaves appear rich in intrinsic defenses due to their thickened and tannin-rich nature. 


\section{Acknowledgements}

We thank Alice Tangerini for the botanical illustration, Stanley Yankowski for the floral anatomy, Marcelo Pace for the description of gross wood structure, Ana S. S. de Holanda for sharing further observations on pollination biology, Peter Endress for stamen perspectives, Paul Berry and Domingos Cardoso for constructive comments, the NMNH Scanning Electron Microscopy Lab, and MO, NY, and US for relevant collections. For fieldwork, we thank the other members of the 2012 Kamakusa Expedition including Aleks Radosavljevic, Karen Redden, Erin Tripp, and the Amerindian team led by James Ralph. That expedition was supported by the National Geographic Society / Waitt Grants Program (Redden, PI), and the Biological Diversity of the Guiana Shield Program (BDG) of the Smithsonian Institution.

\section{References}

Acevedo-Rodríguez P, Strong MT (2012) Catalogue of seed plants of the West Indies. Smithsonian Contributions to Botany 98: 1-1192. https://doi.org/10.5479/si.0081024X.98.1

Bardon L (2015) Phylogénomique et histoire évolutive de deux familles de plantes à fleurs tropicales. PhD Thesis, Université Toulouse, France.

Belin-Depoux M (1993) Importance des nectaires extra-floraux dans les interactions plantesfourmis. Acta Botanica Gallica 140(2): 183-205. https://doi.org/10.1080/12538078.199 3.10515582

Bove CP, Melhem TS (2000) Humiriaceae Juss. World Pollen and Spore Flora 22: 1-35.

Cuatrecasas J (1961) A taxonomic revision of the Hurmiriaceae. Contributions from the United States National Herbarium 35: 25-214.

Cuatrecasas J (1991) Miscellaneous notes on neotropical flora XX. A new species of Humiriastrum. Phytologia 71: 165-166.

Cuatrecasas J, Huber O (1999) Humiriaceae. In: Berry PE, Yatskievych K, Holst BK (Eds) Flora of the Venezuelan Guayana. Volume 5 Eriocaulaceae-Lentibulariaceae. Missouri Botanical Garden Press, St. Louis, 623-641.

Endress PK, Stumpf S (1990) Non-tetrasporangiate stamens in the angiosperms: Structure, systematic distribution and evolutionary aspects. Botanische Jahrbücher für Systematik, Pflanzengeschichte und Pflanzengeographie 112: 193-240.

Endress PK, Stumpf S (1991) The diversity of stamen structures in 'Lower' Rosidae (Rosales, Fabales, Proteales, Sapindales). Botanical Journal of the Linnean Society 107(3): 217-293. https://doi.org/10.1111/j.1095-8339.1991.tb00225a.x

Endress PK, Davis CC, Matthews ML (2013) Advances in the floral structural characterization of the major subclades of Malpighiales, one of the largest orders of flowering plants. Annals of Botany 111(5): 969-985. https://doi.org/10.1093/aob/mct056

Engel J, Sabatier D (2018) Vantanea maculicarpa (Humiriaceae): A new tree species from French Guiana. Phytotaxa 338(1): 130-134. https://doi.org/10.11646/phytotaxa.338.1.12 
Funk V, Hollowell T, Berry P, Kelloff C, Alexander SN (2007) Checklist of the plants of the Guiana Shield (Venezuela: Amazonas, Bolivar, Delta Amacuro; Guyana, Surinam, French Guiana). Contributions from the United States National Herbarium 55: 1-584.

Giordano LCS, Bove CP (2008) Taxonomic considerations and amended description of Humiriastrum spiritu-sancti, Humiriaceae. Rodriguésia 59(1): 151-154. https://doi. org/10.1590/2175-7860200859109

Gonçalves-Souza P, Gonçalves EG, Paiva EAS (2016) Extrafloral nectaries in Philodendron (Araceae): Distribution and structure. Botanical Journal of the Linnean Society 180(2): 229-240. https://doi.org/10.1111/boj.12366

Herrera F, Manchester SR, Jaramillo C, MacFadden B, da Silva-Caminha SA (2010) Phytogeographic history and phylogeny of the Humiriaceae. International Journal of Plant Sciences 171(4): 392-408.https://doi.org/10.1086/651229

Herrera F, Manchester SR, Jaramillo C (2012) Permineralized fruits from the late Eocene of Panama give clues of the composition of forests established early in the uplift of Central America. Review of Palaeobotany and Palynology 175: 10-24. https://doi.org/10.1016/j. revpalbo.2012.02.007

Herrera F, Manchester SR, Vélez-Juarbe J, Jaramillo C (2014) Phytogeographic history of the Humiriaceae (Part 2). International Journal of Plant Sciences 175(7): 828-840. https:// doi.org/10.1086/676818

Holanda ASS (2013) Estudo taxonômico de Humiriaceae no Parque Nacional do Viruá e biologia reprodutiva de duas variedades de Humiria balsamifera Aubl. MSc Thesis, INPA, Manaus, Brazil.

Holanda ASS, Vicentini A, Hopkins MJG, Zartman CE (2015) Phenotypic differences are not explained by pre-zygotic reproductive barriers in sympatric varieties of the Humiria balsamifera complex (Humiriaceae). Plant Systematics and Evolution 301(6): 1767-1779. https://doi.org/10.1007/s00606-014-1191-9

Hufford LD, Endress PK (1989) The diversity of anther structures and dehiscence patterns among Hamamelididae. Botanical Journal of the Linnean Society 99(4): 301-346. https:// doi.org/10.1111/j.1095-8339.1989.tb00406.x

Kelloff CL, Alexander SN, Funk VA, Clarke HD (2011) Smithsonian plant collections, Guyana 1995-2004, H. David Clarke. Smithsonian Contributions to Botany 97: 1-307. https:// doi.org/10.5479/si.0081024X.97.1

Kubitzki K (2014) Humiriaceae. In: Kubitzki K (Ed.) The families and genera of vascular plants. Volume XI. Flowering plants. Eudicots. Malpighiales, Springer-Verlag, Berlin Heidelberg, Germany, 223-228. https://doi.org/10.1007/978-3-642-39417-1_13

Lobova TA, Geiselman CK, Mori SA (2009) Seed dispersal by bats in the Neotropics. Memoirs of the New York Botanical Garden 101: 1-471.

Marazzi B, Sanderson MJ (2010) Large-scale patterns of diversification in the widespread legume genus Senna and the evolutionary role of extrafloral nectaries. Evolution 64(12): 3570-3592. https://doi.org/10.1111/j.1558-5646.2010.01086.x

Marazzi B, Conti E, Sanderson MJ, McMahon MM, Bronstein JL (2012) Diversity and evolution of a trait mediating ant-plant interactions: Insights from extrafloral nectaries in 
Senna (Leguminosae). Annals of Botany 111(6): 1263-1275. https://doi.org/10.1093/ aob/mcs 226

McPherson G (1988) A new species of Vantanea (Humiriaceae) from Panama. Annals of the

Missouri Botanical Garden 75(3): 1148-1149. https://doi.org/10.2307/2399383

Metcalfe CR, Chalk L (1950) Anatomy of the Dicotyledons. Vol. 1. Oxford University Press, London, 1-724.

Narayana LL, Rao D (1969) Contributions to the floral anatomy of the Humiriaceae 1. Shokubutsu Kenkyu Zasshi 44: 328-335. [Vantanea]

Narayana LL, Rao D (1973a) Contributions to the floral anatomy of the Humiriaceae 2. Shokubutsu Kenkyu Zasshi 48: 143-146. [Humiriastrum]

Narayana LL, Rao D (1973b) Contributions to the floral anatomy of the Humiriaceae 3. Shokubutsu Kenkyu Zasshi 48: 242-246. [Humiria]

Narayana LL, Rao D (1976a) Contributions to the floral anatomy of the Humiriaceae 4. Shokubutsu Kenkyu Zasshi 51: 12-15. [Sacoglottis]

Narayana LL, Rao D (1976b) Contributions to the floral anatomy of the Humiriaceae 5. Shokubutsu Kenkyu Zasshi 51: 42-44. [Schistostemon]

Narayana LL, Rao D (1977) Contributions to the floral anatomy of the Humiriaceae 6. Shokubutsu Kenkyu Zasshi 52: 145-153. [Summary]

Nogueira A, Rey PJ, Lohmann LG (2012) Evolution of extrafloral nectaries: Adaptive process and selective regime changes from forest to savanna. Journal of Evolutionary Biology 25(11): 2325-2340. https://doi.org/10.1111/j.1420-9101.2012.02615.x

Rico-Gray V, Oliveira PS (2007) The ecology and evolution of ant-plant interactions. University of Chicago Press, Chicago and London. https://doi.org/10.7208/chicago/9780226713540.001.0001

Roth WW (1923) Richard Schomburgk's travels in British Guiana 1840-1844, Volume II. Daily Chronicle, Georgetown, 1-443. https://doi.org/10.5962/bhl.title.105205

Tilney PM, van Wyk AE (2004) Extrafloral nectaries in Combretaceae: Morphology, anatomy and taxonomic significance. Bothalia 34(2): 115-126. https://doi.org/10.4102/abc. v34i2.426

van Dam JAC (2002) The Guyanan plant collections of Robert and Richard Schomburgk. In: Jansen-Jacobs MJ (Ed.) Flora of the Guianas, Supplementary Series Fascicle 3. Royal Botanic Gardens, Kew, 1-211.

van der Ham R, van Andel T, Butcher L, Hanno I, Lambrechts T, Lincicome K, Mikkelsen P, Mina J, Patterson B, Perry E, Romance M (2015) Furrowed blister pods stranded on northern Atlantic Ocean coasts represent an undescribed Sacoglottis (Humiriaceae) endocarp most similar to the fossil, Sacoglottis costata. Journal of the Botanical Research Institute of Texas 9: 137-147.

van Roosmalen MGM (1985) Fruits of the Guianan flora. Institute of Systematic Botany, Utrecht University and Silvicultural Department of Wageningen Agricultural University, Wageningen, The Netherlands, 1-483.

Weber MG, Agrawal AA (2014) Defense mutualisms enhance plant diversification. Proceedings of the National Academy of Sciences of the United States of America 111(46): 1644216447. https://doi.org/10.1073/pnas.1413253111 
Weber MG, Keeler KH (2013) The phylogenetic distribution of extrafloral nectaries in plants. Annals of Botany 111(6): 1251-1261. https://doi.org/10.1093/aob/mcs225

Weber MG, Porturas LD, Keeler KH (2015) World list of plants with extrafloral nectaries. http://www.extrafloralnectaries.org [accessed 6 Mar 2019]

Wurdack KJ, Davis CC (2009) Malpighiales phylogenetics: Gaining ground on one of the most recalcitrant clades in the angiosperm tree of life. American Journal of Botany 96(8): 1551-1570. https://doi.org/10.3732/ajb.0800207

Wurdack K, Tripp E, Radosavljevic A, Redden K (2013) Kamakusa Expedition 2012: First botanical exploration of a remote Guyana tepui. The Plant Press 16(1), n.s.: 8-10. http:// botany.si.edu/pubs/plantpress/vol16no1.pdf

Xi Z, Rhufel BR, Schaefer H, Amorim AM, Sugumaran M, Wurdack KJ, Endress PK, Mathews ML, Stevens PF, Mathews S, Davis CC (2012) Phylogenomics and a posteriori data partitioning resolve the Cretaceous angiosperm radiation Malpighiales. Proceedings of the National Academy of Sciences of the United States of America 109(43): 17519-17524. https://doi.org/10.1073/pnas.1205818109

\section{Appendix I}

Qualitative survey of Humiriaceae for extrafloral nectaries and leaf margin features. For abaxial glands not near margins, relative exmedial distances (midvein to margin) are indicated where patterns are apparent.

\begin{tabular}{|c|c|c|c|c|}
\hline Taxon & Abaxial glands & $\begin{array}{c}\text { Basilaminar } \\
\text { (adaxial) glands }\end{array}$ & $\begin{array}{c}\text { Leaf margin } \\
\text { features }\end{array}$ & $\begin{array}{c}\text { Representative } \\
\text { voucher }(s)\end{array}$ \\
\hline \multicolumn{5}{|l|}{ Duckesia } \\
\hline $\begin{array}{l}\text { D. liesneri (Cuatrec.) } \\
\text { K. Wurdack \& C.E. } \\
\text { Zartman }\end{array}$ & Absent & $1-2$ pairs at margin & $\begin{array}{l}\text { Crenate, setae } \\
\text { present }\end{array}$ & $\begin{array}{c}\text { Liesner \& Carnevali } \\
22589 \text { (US, } \\
\text { holotype) }\end{array}$ \\
\hline $\begin{array}{l}\text { D. verrucosa (Ducke) } \\
\text { Cuatrec. }\end{array}$ & $\begin{array}{c}\text { Sparse, } 0-3 \text { per } \\
\text { leaf, } 2 / 3 \text { exmedial } \\
\text { distance }\end{array}$ & Absent & $\begin{array}{l}\text { Crenate, setae } \\
\text { present, large }\end{array}$ & Ducke 2106 (US) \\
\hline \multicolumn{5}{|l|}{ Endopleura } \\
\hline E. uchi (Huber) Cuatrec. & Row near margin & Absent & $\begin{array}{l}\text { Crenate, setae long } \\
\text { and scars large }\end{array}$ & Assunção 605 (US) \\
\hline \multicolumn{5}{|l|}{ Humiria } \\
\hline $\begin{array}{l}\text { H. balsamifera var. } \\
\text { coriacea Cuatrec. }\end{array}$ & $\begin{array}{l}\text { Marginal, along } \\
\text { proximal third }\end{array}$ & Absent & Entire & $\begin{array}{c}\text { Cardona } 1823 \text { (US, } \\
\text { holotype) }\end{array}$ \\
\hline $\begin{array}{l}\text { H. balsamifera var. } \\
\text { floribunda (Mart.) } \\
\text { Cuatrec. }\end{array}$ & $\begin{array}{l}\text { Marginal, along } \\
\text { entire length }\end{array}$ & Absent & Entire & $\begin{array}{l}\text { Maguire \& Politi } \\
27974 \text { (US) }\end{array}$ \\
\hline $\begin{array}{l}\text { H. balsamifera var. } \\
\text { guaiquinimana Cuatrec. }\end{array}$ & $\begin{array}{l}\text { Marginal, along } \\
\text { proximal third }\end{array}$ & Absent & Entire & $\begin{array}{c}\text { Cardona } 1112 \text { (US, } \\
\text { holotype) }\end{array}$ \\
\hline $\begin{array}{l}\text { H. balsamifera var. } \\
\text { guianensis (Benth.) } \\
\text { Cuatrec. }\end{array}$ & $\begin{array}{l}\text { Marginal, along } \\
\text { entire length }\end{array}$ & Absent & Entire & $\begin{array}{l}\text { Schomburgk } 270 \\
\text { (US, isotype) }\end{array}$ \\
\hline $\begin{array}{l}\text { H. balsamifera var. iluana } \\
\text { Cuatrec. }\end{array}$ & $\begin{array}{l}\text { Marginal, along } \\
\text { proximal half }\end{array}$ & Absent & Entire & $\begin{array}{c}\text { Maguire } 33388 \text { (US, } \\
\text { holotype) }\end{array}$ \\
\hline $\begin{array}{l}\text { H. balsamifera var. } \\
\text { imbaimadaiensis Cuatrec. }\end{array}$ & $\begin{array}{l}\text { Marginal, along } \\
\text { proximal half }\end{array}$ & Absent & Entire & $\begin{array}{c}\text { Maguire \& Fanshawe } \\
32158 \text { (US, } \\
\text { holotype) }\end{array}$ \\
\hline
\end{tabular}




\begin{tabular}{|c|c|c|c|c|}
\hline Taxon & Abaxial glands & $\begin{array}{c}\text { Basilaminar } \\
\text { (adaxial) glands }\end{array}$ & $\begin{array}{c}\text { Leaf margin } \\
\text { features }\end{array}$ & $\begin{array}{c}\text { Representative } \\
\text { voucher }(s)\end{array}$ \\
\hline $\begin{array}{l}\text { H. balsamifera var. } \\
\text { laurina (Urb.) Cuatrec. }\end{array}$ & $\begin{array}{c}\text { Marginal, along } \\
\text { entire length }\end{array}$ & Absent & Entire & $\begin{array}{c}\text { Schomburgk } 560 \\
\text { (US, isotype) }\end{array}$ \\
\hline $\begin{array}{l}\text { H. balsamifera var. } \\
\text { minarum Cuatrec. }\end{array}$ & $\begin{array}{l}\text { Marginal, along } \\
\text { entire length }\end{array}$ & Absent & Entire & $\begin{array}{c}\text { Mexia } 5815 \text { (US, } \\
\text { holotype) }\end{array}$ \\
\hline $\begin{array}{l}\text { H. balsamifera var. } \\
\text { parvifolia (A. Juss.) } \\
\text { Cuatrec. }\end{array}$ & $\begin{array}{l}\text { Marginal, along } \\
\text { proximal half }\end{array}$ & Absent & Entire & $\begin{array}{l}\text { St. Hilaire (US, } \\
\text { isotype fragment) }\end{array}$ \\
\hline $\begin{array}{l}\text { H. balsamifera var. pilosa } \\
\text { (Steyerm.) Cuatrec. }\end{array}$ & $\begin{array}{l}\text { Marginal, along } \\
\text { entire length }\end{array}$ & Absent & Entire & $\begin{array}{l}\text { Steyermark } 60289 \\
\text { (NY, isotype) }\end{array}$ \\
\hline $\begin{array}{l}\text { H. balsamifera var. } \\
\text { savannarum (Gleason) } \\
\text { Cuatrec. }\end{array}$ & $\begin{array}{c}\text { Marginal, along } \\
\text { entire length or } \\
\text { proximal half }\end{array}$ & Absent & Entire & $\begin{array}{c}\text { Tate } 330(\mathrm{NY}, \\
\text { type); J. Wurdack \& } \\
\text { Monachino } 41380 \\
\text { (US) }\end{array}$ \\
\hline $\begin{array}{l}\text { H. balsamifera var. } \\
\text { stenocarpa Cuatrec. }\end{array}$ & $\begin{array}{l}\text { Marginal, along } \\
\text { entire length }\end{array}$ & Absent & Entire & $\begin{array}{c}\text { Maguire \& Maguire } \\
40105 \text { (US, } \\
\text { holotype) }\end{array}$ \\
\hline $\begin{array}{l}\text { H. balsamifera var. } \\
\text { subsessilis (Urb.) Cuatrec. }\end{array}$ & $\begin{array}{c}\text { Marginal, dense } \\
\text { along entire length }\end{array}$ & Absent & Entire & $\begin{array}{c}\text { Spruce } 2454 \text { (US, } \\
\text { isotype) }\end{array}$ \\
\hline H. crassifolia Mart. & $\begin{array}{l}\text { Marginal, sparse, } \\
\text { denser at base and } \\
\text { apex }\end{array}$ & Absent & Entire & $\begin{array}{c}\text { Huber \& Fernandez } \\
11331 \text { (US) }\end{array}$ \\
\hline H. fruticosa Cuatrec. & $\begin{array}{l}\text { Marginal, 2-4 per } \\
\text { side near base }\end{array}$ & Absent & Entire & $\begin{array}{c}\text { Maguire et al. } 36580 \\
\text { (US, holotype) }\end{array}$ \\
\hline H. wurdackii Cuatrec. & \begin{tabular}{|} 
Marginal, along \\
entire length, widely \\
spaced; absent on \\
very narrow forms
\end{tabular} & Absent & Entire & $\begin{array}{c}J . \text { Wurdack \& } \\
\text { Adderley } 42760 \text { (US, } \\
\text { holotype); Huber } \\
4842 \text { (US), narrow- } \\
\text { leaved }\end{array}$ \\
\hline \multicolumn{5}{|l|}{ Humiriastrum } \\
\hline $\begin{array}{l}\text { H. columbianum } \\
\text { (Cuatrec.) Cuatrec. }\end{array}$ & $\begin{array}{c}\text { Sparse abaxial; absent } \\
\text { on type, save for a } \\
\text { few erratic structures } \\
\text { that could be } \\
\text { damage. }\end{array}$ & Absent & Serrate, setae long & $\begin{array}{c}\text { Lamb } 141 \text { (US, } \\
\text { holotype); best gland } \\
\text { evidence is on Gentry } \\
\text { \& Stein } 46898 \text { (US); } \\
\text { Romero Castañeda } \\
4942 \text { (US) }\end{array}$ \\
\hline $\begin{array}{l}\text { H. cuspidatum (Benth.) } \\
\text { Cuatrec. }\end{array}$ & $\begin{array}{l}\text { Small, sparse, near } \\
\text { margin }\end{array}$ & 1 pair, elliptic & $\begin{array}{l}\text { Crenate, setae long } \\
\text { and thin }\end{array}$ & $\begin{array}{c}\text { J. Wurdack \& } \\
\text { Monachino } 40881 \\
\text { (US) }\end{array}$ \\
\hline $\begin{array}{l}\text { H. cuspidatum var. } \\
\text { glabriflorum (Ducke) } \\
\text { Cuatrec. }\end{array}$ & $\begin{array}{l}\text { Small, sparse, near } \\
\text { margin }\end{array}$ & $\begin{array}{c}1 \text { pair at margin } \\
\text { (sometimes a single } \\
\text { gland) }\end{array}$ & Serrate, setae scars & $\begin{array}{c}\text { Ducke [JBRJ-23436] } \\
\text { (US, isotype) }\end{array}$ \\
\hline $\begin{array}{l}\text { H. cuspidatum var. } \\
\text { subhirtellum Cuatrec. }\end{array}$ & $\begin{array}{l}\text { Small, sparse, near } \\
\text { margin }\end{array}$ & $0-1$ pair & Serrate, setae present & Fróes 25463 (US) \\
\hline $\begin{array}{l}\text { H. dentatum (Casar.) } \\
\text { Cuatrec. }\end{array}$ & $\begin{array}{l}\text { Small, sparse, near } \\
\text { margin }\end{array}$ & $\begin{array}{l}1 \text { pair at margin, } \\
\text { nearly abaxial }\end{array}$ & Serrate, setae present & $\begin{array}{c}\text { Hatschbach } 4294 \\
\text { (US) }\end{array}$ \\
\hline $\begin{array}{l}\text { H. diguense (Cuatrec.) } \\
\text { Cuatrec. }\end{array}$ & $\begin{array}{l}\text { Along secondary vein } \\
\text { loops toward margin }\end{array}$ & $\begin{array}{c}\text { 1-3 pairs at margin, } \\
\text { nearly abaxial }\end{array}$ & Crenate, setae scars & $\begin{array}{c}\text { Cuatrecasas } 14956 \\
\text { (US, isotype) }\end{array}$ \\
\hline $\begin{array}{l}\text { H. diguense var. } \\
\text { anchicayanum (Cuatrec.) } \\
\text { Cuatrec. }\end{array}$ & $\begin{array}{l}\text { Along secondary vein } \\
\text { loops toward margin }\end{array}$ & $\begin{array}{l}1 \text { pair at margin, } \\
\text { nearly abaxial }\end{array}$ & Crenate, setae scars & $\begin{array}{c}\text { Cuatrecasas } 14418 \\
\text { (US, isotype) }\end{array}$ \\
\hline $\begin{array}{l}\text { H. diguense subsp. } \\
\text { costaricense Cuatrec. }\end{array}$ & $\begin{array}{c}\text { Along secondary vein } \\
\text { loops toward margin, } \\
\text { relatively sparse }\end{array}$ & 1 pair & $\begin{array}{l}\text { Crenate, setae } \\
\text { relatively stout, } \\
\text { clearly terminating } \\
\text { veins }\end{array}$ & $\begin{array}{c}\text { Allen } 5812 \text { (US, } \\
\text { holotype) }\end{array}$ \\
\hline
\end{tabular}




\begin{tabular}{|c|c|c|c|c|}
\hline Taxon & Abaxial glands & $\begin{array}{c}\text { Basilaminar } \\
\text { (adaxial) glands }\end{array}$ & $\begin{array}{c}\text { Leaf margin } \\
\text { features }\end{array}$ & $\begin{array}{c}\text { Representative } \\
\text { voucher(s) }\end{array}$ \\
\hline $\begin{array}{l}\text { H. excelsum (Ducke) } \\
\text { Cuatrec. }\end{array}$ & $\begin{array}{c}\text { Near secondary vein } \\
\text { loops toward margin, } \\
\text { relatively sparse }\end{array}$ & 1 pair at margin & $\begin{array}{l}\text { Crenate, setae } \\
\text { present }\end{array}$ & $\begin{array}{c}\text { Museu Goeldi } 9672 \\
\text { (US) }\end{array}$ \\
\hline $\begin{array}{l}\text { H. glaziovii (Urb.) } \\
\text { Cuatrec. }\end{array}$ & Absent & $\begin{array}{l}1 \text { pair at margin, } \\
\text { nearly abaxial }\end{array}$ & Serrate, setae present & Pabst 4726 (US) \\
\hline $\begin{array}{l}\text { H. glaziovii var. } \\
\text { angustifolium Cuatrec. }\end{array}$ & Absent & $\begin{array}{l}1 \text { pair at margin, } \\
\text { nearly abaxial }\end{array}$ & Crenate, setae scars & $\begin{array}{c}\text { Glaziou } 16724 \text { (US, } \\
\text { holotype) }\end{array}$ \\
\hline H. mapiriense Cuatrec. & $\begin{array}{l}\text { Sparse, toward } \\
\text { margin }\end{array}$ & $0-2$ pairs & Crenate, setae scars & $\begin{array}{c}\text { Buchtien } 1518 \text { (US, } \\
\text { isotype) }\end{array}$ \\
\hline $\begin{array}{l}\text { H. melanocarpum } \\
\text { (Cuatrec.) Cuatrec. }\end{array}$ & $\begin{array}{c}\text { Very rare on few } \\
\text { leaves, scattered, hard } \\
\text { to distinguish from } \\
\text { potential leaf damage }\end{array}$ & Absent & Crenate, with setae & $\begin{array}{l}\text { Cuatrecasas } 19909 \\
\text { (US); best gland } \\
\text { evidence is on Prance } \\
28055 \text { (US) }\end{array}$ \\
\hline $\begin{array}{l}\text { H. mussunungense } \\
\text { Cuatrec. }\end{array}$ & Absent & $\begin{array}{c}\text { 0-1 pair at margin, } \\
\text { nearly abaxial }\end{array}$ & $\begin{array}{c}\text { Crenate, setae } \\
\text { present }\end{array}$ & $\begin{array}{c}\text { Folli } 1393 \text { (US, } \\
\text { holotype) }\end{array}$ \\
\hline $\begin{array}{l}\text { H. obovatum (Benth.) } \\
\text { Cuatrec. }\end{array}$ & Sparse, scattered & $\begin{array}{c}0-1 \text { pair at margin, } \\
\text { nearly abaxial }\end{array}$ & \begin{tabular}{|c|} 
Subentire, setae scars \\
sparse, hirsute
\end{tabular} & $\begin{array}{c}\text { Schomburgk } 1359 \\
\text { (US) }\end{array}$ \\
\hline H. ottohuberi Cuatrec. & Row near margin & $1-3$ pairs, oval & $\begin{array}{c}\text { Obscurely crenate, } \\
\text { setae present }\end{array}$ & $\begin{array}{c}\text { Steyermark \& } \\
\text { Bunting } 102442 \text { (US, } \\
\text { holotype) }\end{array}$ \\
\hline H. piraparanense Cuatrec. & $\begin{array}{l}\text { Tiny, sparse, near } \\
\text { margin }\end{array}$ & $1-2$ pairs & Crenate, setae scars & $\begin{array}{c}\text { Schultes \& Cabrera } \\
15922 \text { (US, } \\
\text { holotype); glands } \\
\text { better developed } \\
\text { on García-Barriga } \\
14287 \text { (US) }\end{array}$ \\
\hline $\begin{array}{l}\text { H. procerum (Little) } \\
\text { Cuatrec. }\end{array}$ & \begin{tabular}{|c|} 
Towards margin \\
along loops between \\
secondary veins
\end{tabular} & $1(-2)$ pairs at margin & Crenate, setae scars & $\begin{array}{c}\text { Little \& Dixon } 21148 \\
\text { (US) }\end{array}$ \\
\hline $\begin{array}{l}\text { H. subcrenatum (Benth.) } \\
\text { Cuatrec. }\end{array}$ & Absent & 1 pair at margin & Crenate, setae scars & $\begin{array}{l}\text { Martin s.n. (US, type } \\
\text { fragment) }\end{array}$ \\
\hline $\begin{array}{l}\text { H. villosum (Fróes) } \\
\text { Cuatrec. }\end{array}$ & $\begin{array}{c}\text { Tiny, sparse, in row } \\
\text { near margin }\end{array}$ & $\begin{array}{c}1 \text { pair at margin, } \\
\text { small }\end{array}$ & Serrate, setae scars & $\begin{array}{c}\text { Humbert \& Schultes } \\
27363 \text { (US) }\end{array}$ \\
\hline \multicolumn{5}{|l|}{ Hylocarpa } \\
\hline $\begin{array}{l}\text { H. heterocarpa (Ducke) } \\
\text { Cuatrec. }\end{array}$ & \begin{tabular}{|c|} 
Large, erratic, \\
near secondary or \\
intersecondary veins, \\
$1 / 2-2 / 3$ exmedial \\
distance
\end{tabular} & Absent & Subentire, setae scars & $\begin{array}{c}\text { Ducke [JBRJ-30137] } \\
\text { (US, isotype }\end{array}$ \\
\hline \multicolumn{5}{|l|}{ Sacoglottis } \\
\hline S. amazonica Mart. & Small, near margin & 1 pair & $\begin{array}{c}\text { Obscurely crenate, } \\
\text { setae scars }\end{array}$ & J. Wurdack 293 (US) \\
\hline S. ceratocarpa Ducke & $\begin{array}{c}\text { Relatively large, near } \\
\text { margin }\end{array}$ & $\begin{array}{l}1 \text { pair, large, } \\
\text { narrowly elliptic, at } \\
\text { margin of leaf base } \\
\text { extension }\end{array}$ & $\begin{array}{c}\text { Subentire, setae } \\
\text { present }\end{array}$ & Fróes 21192 (US) \\
\hline S. cydonioides Cuatrec. & Tiny, near margin & $\begin{array}{l}1 \text { pair, elliptic, } \\
\text { sometimes large }\end{array}$ & $\begin{array}{c}\text { Serrate, tooth tips } \\
\text { with darkened spots } \\
\text { (setae scars?) }\end{array}$ & $\begin{array}{c}\text { B.W. [Surinam } \\
\text { Forestry Dept.] } 4720 \\
\text { (US) }\end{array}$ \\
\hline S. gabonensis (Baill.) Urb. & Absent & 1(-2) pairs at margin & $\begin{array}{c}\text { Crenate, setae } \\
\text { present }\end{array}$ & $\begin{array}{c}\text { McPherson } 13714 \\
\text { (US) }\end{array}$ \\
\hline S. guianensis Benth. & $\begin{array}{l}\text { Small, row near } \\
\text { margin }\end{array}$ & $0-1$ pair at margin & $\begin{array}{l}\text { Shallowly crenate; } \\
\text { setae present, more } \\
\text { persistent than is } \\
\text { typical }\end{array}$ & $\begin{array}{c}\text { Schomburgk } 574 \\
\text { (NY, syntype) }\end{array}$ \\
\hline
\end{tabular}




\begin{tabular}{|c|c|c|c|c|}
\hline Taxon & Abaxial glands & $\begin{array}{c}\text { Basilaminar } \\
\text { (adaxial) glands }\end{array}$ & $\begin{array}{c}\text { Leaf margin } \\
\text { features }\end{array}$ & $\begin{array}{c}\text { Representative } \\
\text { voucher(s) }\end{array}$ \\
\hline $\begin{array}{l}\text { S. guianensis var. hispidula } \\
\text { Cuatrec. }\end{array}$ & Tiny, near margin & Absent & Serrulate, setae scars & $\begin{array}{c}\text { Krukoff } 6653 \text { (US, } \\
\text { holotype) }\end{array}$ \\
\hline $\begin{array}{l}\text { S. guianensis var. maior } \\
\text { Ducke }\end{array}$ & $\begin{array}{l}\text { Small, row near } \\
\text { margin }\end{array}$ & Absent & $\begin{array}{c}\text { Crenate; setae more } \\
\text { persistent than is } \\
\text { typical }\end{array}$ & $\begin{array}{c}\text { Ducke [JBRJ-23818 } \\
\text { (US, isotype) }\end{array}$ \\
\hline S. holdridgei Cuatrec. & $\begin{array}{l}\text { Small, row near } \\
\text { margin }\end{array}$ & $1(-2)$ pairs & $\begin{array}{c}\text { Shallowly crenate, } \\
\text { setae scars }\end{array}$ & $\begin{array}{c}\text { Holdridge } 5164 \text { (US, } \\
\text { isotype) }\end{array}$ \\
\hline S. maguirei Cuatrec. & $\begin{array}{c}\text { Sparse }(0-2), \text { tiny, } \\
\text { near leaf apex } \\
\text { margin, most leaves } \\
\text { lacking }\end{array}$ & Absent & $\begin{array}{l}\text { Shallowly crenate, } \\
\text { setae scars }\end{array}$ & $\begin{array}{l}\text { Maguire et al. } 30693 \\
\text { (US, holotype) }\end{array}$ \\
\hline $\begin{array}{l}\text { S. mattogrossensis var. } \\
\text { subintegra (Ducke) } \\
\text { Cuatrec. }\end{array}$ & $\begin{array}{l}\text { Small, sparse, near } \\
\text { margin }\end{array}$ & Absent & $\begin{array}{c}\text { Subentire, setae scars } \\
\text { obscure }\end{array}$ & $\begin{array}{c}\text { Ducke [JBRJ-23820] } \\
\text { (US, isotype) }\end{array}$ \\
\hline S. ovicarpa Cuatrec. & Absent & 1 pair & Subentire, setae scars & $\begin{array}{c}\text { Cuatrecasas } 17226 \\
\text { (US) }\end{array}$ \\
\hline $\begin{array}{l}\text { S. perryi K. Wurdack \& } \\
\text { C.E. Zartman }\end{array}$ & Tiny, near margin & $\begin{array}{l}1 \text { pair, relatively } \\
\text { small, obscure }\end{array}$ & $\begin{array}{c}\text { Shallowly crenate, } \\
\text { setae present }\end{array}$ & McDowell 2920 (US) \\
\hline S. trichogyna Cuatrec. & Absent & 1 pair & $\begin{array}{c}\text { Shallowly crenate, } \\
\text { setae scars }\end{array}$ & $\begin{array}{c}\text { Holdridge } 5216 \text { (US, } \\
\text { isotype) }\end{array}$ \\
\hline \multicolumn{5}{|l|}{ Schistostemon } \\
\hline $\begin{array}{l}\text { S. auyantepuiensis } \\
\text { Cuatrec. }\end{array}$ & $\begin{array}{c}\text { Tiny, with reticulate } \\
\text { veins near margin }\end{array}$ & 1 pair, large elliptic & $\begin{array}{c}\text { Very obscurely } \\
\text { crenate, setae scars }\end{array}$ & $\begin{array}{c}\text { Davidse \& Huber } \\
22804 \text { (US) }\end{array}$ \\
\hline $\begin{array}{l}\text { S. densiflorus (Urb.) } \\
\text { Cuatrec. }\end{array}$ & $\begin{array}{l}\text { Small, row near } \\
\text { margin }\end{array}$ & $0-1$ pair & $\begin{array}{c}\text { Obscurely crenate, } \\
\text { setae present }\end{array}$ & $\begin{array}{c}\text { Schomburgk } 543 \text { (US } \\
\text { isotype) }\end{array}$ \\
\hline $\begin{array}{l}\text { S. dichotomus (Urb.) } \\
\text { Cuatrec. }\end{array}$ & $\begin{array}{l}\text { Small, row near } \\
\text { margin }\end{array}$ & 1 pair & Crenate, setae scars & Sabatier 989 (US) \\
\hline S. fernandezii Cuatrec. & Near margin & 1 pair, oval & $\begin{array}{l}\text { Obscurely crenate, } \\
\text { small setae present }\end{array}$ & $\begin{array}{c}\text { Fernandez } 2276 \text { (US, } \\
\text { holotype) }\end{array}$ \\
\hline $\begin{array}{l}\text { S. macrophyllus (Benth.) } \\
\text { Cuatrec. }\end{array}$ & $\begin{array}{c}\text { Row near margin, } \\
\text { widely spaced }\end{array}$ & 1 pair, elliptic & $\begin{array}{c}\text { Shallow teeth, setae } \\
\text { scars }\end{array}$ & Ducke 1744 (US) \\
\hline $\begin{array}{l}\text { S. oblongifolius (Benth.) } \\
\text { Cuatrec. }\end{array}$ & Near margin & 1-2 pairs & $\begin{array}{c}\text { Small, shallow teeth, } \\
\text { setae scars }\end{array}$ & $\begin{array}{c}\text { Maas et al. } 6804 \\
\text { (US) }\end{array}$ \\
\hline $\begin{array}{l}\text { S. reticulatus (Ducke) } \\
\text { Cuatrec. }\end{array}$ & Near margin & $\begin{array}{c}\text { 1-2 pairs at base, up } \\
\text { to } 3 \text { per side near } \\
\text { apex }\end{array}$ & Obscurely crenate & $\begin{array}{c}\text { Ducke [JBRJ-23819] } \\
\text { (US, isotype), Klug } \\
1564 \text { (US) }\end{array}$ \\
\hline $\begin{array}{l}\text { S. reticulatus var. froesii } \\
\text { Cuatrec. }\end{array}$ & Near margin & $\begin{array}{l}1 \text { pair at base, no } \\
\text { glands at apex }\end{array}$ & $\begin{array}{c}\text { Subentire, setae scars } \\
\text { sparse }\end{array}$ & $\begin{array}{c}\text { Fróes } 21370 \text { (US, } \\
\text { isotype) }\end{array}$ \\
\hline $\begin{array}{l}\text { S. retusus (Ducke) } \\
\text { Cuatrec. }\end{array}$ & $\begin{array}{l}\text { Near margin, } \\
\text { relatively regular all } \\
\text { the way to tip }\end{array}$ & 1 pair, large & $\begin{array}{c}\text { Subentire, setae scars } \\
\text { sparse }\end{array}$ & $\begin{array}{c}\text { Cuatrecasas } 7203 \\
\text { (US) }\end{array}$ \\
\hline S. sylvaticus Sabatier & Row near margin & $1-2$ pairs at base & $\begin{array}{c}\text { Very obscurely } \\
\text { crenate, setae scars }\end{array}$ & Loubry 1074 (US) \\
\hline \multicolumn{5}{|l|}{ Vantanea } \\
\hline V. bahiaensis Cuatrec. & $\begin{array}{c}\text { Tiny, near secondary } \\
\text { or intersecondary } \\
\text { veins }\end{array}$ & 1 pair & Entire & $\begin{array}{c}\text { Belém \& Magalhäes } \\
748 \text { (US); Carvalho } \\
\text { \& Gatti } 484 \text { (NY, } \\
\text { holotype) }\end{array}$ \\
\hline V. barbourii Standl. & $\begin{array}{c}\text { Near secondary or } \\
\text { intersecondary veins }\end{array}$ & 1 pair & Entire & Hartshorn 2139 (US) \\
\hline $\begin{array}{l}\text { V. celativenia (Standl.) } \\
\text { Cuatrec. }\end{array}$ & $\begin{array}{c}\text { Row } 1 / 3 \text { exmedial } \\
\text { distance }\end{array}$ & $\begin{array}{c}1 \text { pair, often others } \\
\text { near base }\end{array}$ & Entire & $\begin{array}{c}\text { Krukoff } 7182 \text { (US, } \\
\text { isotype) }\end{array}$ \\
\hline $\begin{array}{l}\text { V. compacta (Schnizl.) } \\
\text { Cuatrec. }\end{array}$ & $\begin{array}{c}\text { Tiny, near } \\
\text { intersecondary veins } \\
\text { near margin }\end{array}$ & $0-4$ pairs per side & Entire & $\begin{array}{c}\text { Hatschbach } 21265 \\
\text { (US) }\end{array}$ \\
\hline
\end{tabular}




\begin{tabular}{|c|c|c|c|c|}
\hline Taxon & Abaxial glands & $\begin{array}{c}\text { Basilaminar } \\
\text { (adaxial) glands }\end{array}$ & $\begin{array}{c}\text { Leaf margin } \\
\text { features }\end{array}$ & $\begin{array}{c}\text { Representative } \\
\text { voucher(s) }\end{array}$ \\
\hline $\begin{array}{l}\text { V. deniseae W.A. } \\
\text { Rodrigues }\end{array}$ & $\begin{array}{c}\text { Near secondary or } \\
\text { intersecondary veins }\end{array}$ & Absent & Entire & $\begin{array}{c}\text { Freitas et al. } 860 \\
\text { (US) }\end{array}$ \\
\hline V. depleta McPherson & $\begin{array}{c}\text { Near secondary } \\
\text { veins, row half } \\
\text { exmedial distance }\end{array}$ & 1 pair & Entire & $\begin{array}{c}\text { McPherson \& } \\
\text { Stockwell } 10892 \text { (US, } \\
\text { isotype) }\end{array}$ \\
\hline V. guianensis Poir. & Scattered & Absent & Entire & $\begin{array}{c}\text { Maguire et al. } 56006 \\
\text { (US) }\end{array}$ \\
\hline V. macrocarpa Ducke & Scattered & Absent & Entire & Ducke 2230 (US) \\
\hline $\begin{array}{l}\text { V. magdalenensis } \\
\text { Cuatrec. }\end{array}$ & $\begin{array}{c}\text { Tiny, near secondary } \\
\text { and intersecondary } \\
\text { veins }\end{array}$ & 1 pair & Entire & $\begin{array}{l}\text { Lamb } 133 \text { (US, } \\
\text { holotype) }\end{array}$ \\
\hline V. micrantha Ducke & Scattered & Absent & Entire & Ducke 751 (US) \\
\hline V. minor Benth. & $\begin{array}{l}\text { Large, sparse, } \\
\text { proximal half near } \\
\text { primary vein }\end{array}$ & Absent & Entire & Liesner 23974 (US) \\
\hline V. morii Cuatrec. & Absent & 2(-4) pairs & Entire & $\begin{array}{l}\text { Mori \& Benton } \\
13181 \text { (US, } \\
\text { holotype) }\end{array}$ \\
\hline V. obovata Benth. & $\begin{array}{c}\text { Near secondary or } \\
\text { intersecondary veins }\end{array}$ & $1-2$ pairs & Entire & $\begin{array}{c}\text { Anderson et al. } 36781 \\
\text { (US) }\end{array}$ \\
\hline $\begin{array}{l}\text { V. occidentalis } \\
\text { Cuatrec. }\end{array}$ & $\begin{array}{c}\text { Large, near } \\
\text { intersecondary veins, } \\
\text { row } 1 / 3 \text { exmedial } \\
\text { distance }\end{array}$ & Absent & Entire & Patiño 12 (US) \\
\hline V. ovicarpa Sabatier & $\begin{array}{l}\text { Tiny, close to } \\
\text { secondary veins }\end{array}$ & $\begin{array}{l}0-1 \text { pair, rarely } \\
\text { others near base }\end{array}$ & Entire & $\begin{array}{c}\text { Granville } 10792 \\
\text { (US) }\end{array}$ \\
\hline$V \cdot$ paraensis Ducke & $\begin{array}{c}\text { Near secondary or } \\
\text { intersecondary veins }\end{array}$ & $\begin{array}{c}1 \text { pair, often others } \\
\text { along secondary near } \\
\text { base }\end{array}$ & Entire & $\begin{array}{c}\text { Ducke [JBRJ-23430] } \\
\text { (US) }\end{array}$ \\
\hline$V$ parviflora Lam. & $\begin{array}{c}\text { Along loops of } \\
\text { secondary veins, near } \\
\text { margin }\end{array}$ & $\begin{array}{c}\text { Row of } 2-4(5) \text { pairs, } \\
\text { usually close to } \\
\text { mid-vein }\end{array}$ & Entire & $\begin{array}{c}\text { Prance et al. } 17770 \\
\text { (US) }\end{array}$ \\
\hline $\begin{array}{l}\text { V. parviflora var. } \\
\text { puberulifolia Cuatrec. }\end{array}$ & \begin{tabular}{|c|} 
Along loops of \\
secondary veins, \\
near margin, usually \\
surrounded by vein
\end{tabular} & $\begin{array}{c}2(1-3) \text { pairs, closer } \\
\text { to midvein }\end{array}$ & Entire & $\begin{array}{c}\text { Ducke [JBRJ-23428] } \\
\text { (US, holotype) }\end{array}$ \\
\hline V. peruviana J.F. Macbr. & $\begin{array}{l}\text { Large, row, mostly } \\
\text { near intersecondary } \\
\text { veins, } 1 / 4-1 / 3 \\
\text { exmedial distance }\end{array}$ & Absent & Entire & Rimachi 4577 (US) \\
\hline V. spichigeri A.H. Gentry & $\begin{array}{l}\text { Row, } 1 / 5 \text { way to } \\
\text { margin, often near } \\
\text { secondary veins }\end{array}$ & $1-2$ pairs & Entire & $\begin{array}{c}\text { Abadie s.n. 12-9-74 } \\
\text { (US), Spichiger et al. } \\
1743 \text { (NY, isotype) }\end{array}$ \\
\hline $\begin{array}{l}\text { V. spiritu-sancti (Cuatrec.) } \\
\text { K. Wurdack \& C.E. } \\
\text { Zartman }\end{array}$ & $\begin{array}{c}\text { Sparse, small } \\
\text { along secondary } \\
\text { or intersecondary } \\
\text { veins, half exmedial } \\
\text { distance }\end{array}$ & $\begin{array}{l}1-2 \text { (type); } 5-7 \text { pairs } \\
\text { along proximal edge }\end{array}$ & Entire & $\begin{array}{c}\text { Dolcolmo [JBRJ- } \\
\text { 86212] (US, isotype } \\
\text { fragment); Silva et } \\
\text { al. } 1436 \text { (US), more } \\
\text { abundant }\end{array}$ \\
\hline V. tuberculata Ducke & $\begin{array}{c}\text { Along secondary } \\
\text { veins, half exmedial } \\
\text { distance } \\
\end{array}$ & Absent & Entire & $\begin{array}{c}\text { Ducke [JBRJ-30134] } \\
\text { (US, isotype) }\end{array}$ \\
\hline
\end{tabular}

